\title{
TURTLE AND PTEROSAUR TRACKS FROM \\ THE LOS CAYOS DINOSAUR TRACKSITE, CAMEROS BASIN (CORNAGO, LA RIOJA, SPAIN): TRACKING THE LOWER CRETACEOUS BIO-DIVERSITY
}

\author{
José J. MORATALLAl and Javier HERNÁN ${ }^{2}$ \\ ${ }^{1}$ Instituto Geológico y Minero de España (Museo Geominero). Ríos Rosas, \\ 23. 28003-Madrid (SPAIN). E-mail: j.moratalla@igme.es \\ ${ }^{2}$ Escuela Técnica Superior de Ingenieros de Minas. Ríos Rosas, 21. 28003-Ma- \\ drid (SPAIN).
}

Moratalla, J. J. \& Hernán, J. 2009. Turtle and pterosaur tracks from the Los Cayos dinosaur tracksite, Cameros Basin (Cornago, La Rioja, Spain): tracking the Lower Cretaceous bio-diversity. [Icnitas de tortugas y pterosaurios del yacimiento de Los Cayos, Cuenca de Cameros (Cornago, La Rioja, España): investigando la biodiversidad del Cretácico Inferior.] Revista Española de Paleontología, 24 (1), 59-77. ISSN 0213-6937.

\begin{abstract}
New fossil turtle and pterosaurian tracks have been found at the Los Cayos locality (Cornago township, La Rioja province, Spain). The Los Cayos tracksite is situated in the Cameros Basin, ant it is included in the Enciso Group, which is late Barremian-Early Aptian in age (Lower Cretaceous).

The turtle tracks are formed by parallel isolated digit impressions. Digits show acuminate distal ends and relatively blunt proximal margins. Most of the tracks show three digits, and only two of them are pentadactyl. No trackways can be observed but only different track alignments suggesting some kind of direction of movement.

Two track-bearing layers have yielded 5 pterosaur manus prints. No pes footprints or trackways have been discovered at these outcrops yet. These prints are tridactyl, with digit I, the shortest, and III, the longest. The angles between the digits are variable: angle I-II is significantly bigger than between II-III. These tracks from Los Cayos were the first discovery of pterosaur tracks in the Enciso Group.
\end{abstract}

Keywords: Paleoichnology, Cameros Basin, Lower Cretaceous, turtles, Emydhipus, pterosaurs, Pteraichnus, Spain.

\section{RESUMEN}

El yacimiento de Los Cayos (término municipal de Cornago, La Rioja, España) ha proporcionado nuevas icnitas fósiles de tortugas y pterosaurios. Este yacimiento se localiza en la Cuenca de Cameros y está incluido en el Grupo Enciso, de edad Barremiense superior-Aptiense inferior (Cretácico Inferior).

Las huellas de tortugas están formadas por impresiones digitales paralelas. Los dedos presentan terminaciones distales acuminadas y márgenes proximales relativamente redondeados. La mayoría de las icnitas muestran tres dedos y sólo dos de ellas son pentadáctilas. No existen rastros aunque sí ciertas alineaciones de huellas que sugieren una determinada dirección de movimiento.

Se han descubierto dos niveles estratigráficos con 5 icnitas de manos de pterosaurios, sin que existan por el momento rastros ni huellas de pies. Las icnitas son tridáctilas con el dedo I, el más corto, y el III, el más largo. Los ángulos interdigitales son variables: el ángulo I-II es significativamente mayor que el II-III. Estas icnitas de pterosaurios de Los Cayos son las primeras referidas en el Grupo Enciso.

Palabras clave: Paleoicnología, Cuenca de Cameros, Cretácico Inferior, quelonios, Emydhipus, pterosaurios, Pteraichnus, España. 


\section{INTRODUCTION}

The Los Cayos dinosaur tracksite is one of the most impressive localities in the European dinosaur track record. It is located in the eastern sector of the Cameros Basin (Cornago township, La Rioja province) (Moratalla \& Sanz, 1997) (see Geological Setting for a more specific location).

More than 150 dinosaur tracksites have been already identified in the Cameros region. Several ichnological sites, each one with several track-bearing layers, are known (Moratalla, 2002). This is the case with the Los Cayos locality. In fact, the Los Cayos area has at least 6 dinosaur track outcrops named Los Cayos A, B, C, D, E and S. Although most of the outcrops show theropod tracks, some of them have yielded ornithopod footprints (Los Cayos D), and sauropod tracks (Los Cayos A and S). We describe herein a series of tiny turtle and pterosaurian tracks located in the same sedimentary levels as the dinosaur footprints. This assemblage sheds light on the bio-diversity of this Lower Cretaceous continental ecosystem. The nice preservation, the number of tracks and trackways, and the orientation/disposition of the exposures make this dinosaur tracksite area an impressive "natural in situ museum" of Paleontology.

The first findings of turtle remains from the Spanish Lower Cretaceous were published by Royo y Gómez (1918, 1921), who reported Helochelys? from Zaragoza province, and Trachyapsis (Dermatemydidae) from Buñol (Valencia province). Some chelonian fossil remains were cited by Jiménez (1987, 1995), and Jiménez et al. (1990). Most of the chelonian fossils come from some of the basins around Cameros: Teruel and Valencia provinces, the Las Hoyas fossil site (Cuenca province) (Jiménez, 1995) and Uña locality, also in Cuenca province (Krebs, 1995). Murelaga (1997) has also cited findings from Vallipón site (Castellote, Teruel province). The Upper Cretaceous has yielded abundant turtle material from Laño (very near Vitoria city) (de Broin \& Murelaga, 1999), and from Armuña (Segovia province) (Buscalioni \& Martínez-Salanova, 1990). More recent findings of turtle tracks and bones have been described from the Upper Jurassic of Asturias (northern Spain) (Garcia-Ramos et al., 2002; Avanzini et al., 2005). The bone material mainly consists of dermal plates, some of them very well preserved, and the tracks are mostly tridactyl, with parallel digit impressions.

Few turtle fossil remains have been described from the Cameros Basin. Those known include remains identified as Dermatemydidae from Salas de los Infantes (Burgos), Alcarama (La Rioja) (Palacios \& Sánchez, 1885; Jiménez et al., 1990), the report of the genus Helochelys (Los Caños, Soria province) (Bataller, 1960) and some scattered and fragmented plates from Sol de la Pita 1 (Préjano) (Jiménez et al., 1990; Moratalla et al., 2001). Previously, Fuentes et al. (2003a) described a new turtle genus (Salasemys) from the Lower Cretaceous of Salas de los Infantes (Bur- gos province, Western Cameros Sub-basin). Unfortunately for the purpose of this paper, mainly isolated carapace plates form this material making it difficult to study and compare their autopodial characteristics. An isolated tridactyl print from Los Cayos A outcrop was described by Moratalla (1990), and the outcrop (Los Cayos C) we are describing in this paper was first mentioned by Moratalla (1993). After about ten years of field work and excavations, no more turtle prints had been discovered in the Cameros Basin until the description of a well preserved turtle trackway from the Valduérteles locality (Soria province) (Fuentes et al., 2003b) and some isolated tracks from Valdelavilla (also Soria province) (Fuentes et al., 2008). This fact suggests that, although the turtles were probably dwellers of riverbanks, streams, and also permanent or ephemeral lakes (abundant in these continental Lower Cretaceous ecosystems) the probability of preservation of their tracks, compared with those of dinosaurs, was relatively low.

Pterosaur fossil bones are relatively scarce in the Spanish fossil record. Some scattered bone fragments were reported from the Laño fossil site (Burgos province) (Upper Cretaceous) (Astibia et al., 1990; Pereda-Suberbiola et al., 1992; Pereda-Suberbiola \& Astibia, 1993; Buffetaut, 1999). Some bones, mainly teeth, were reported from the Lower Cretaceous of Galve (Teruel province) (CuencaBescós et al., 1994). A giant azhadarchid pterosaur was reported from the Upper Cretaceous of Valencia province (Company et al., 2001). Several outcrops with very well preserved pterosaur tracks, some of them even with skin impressions, were described and illustrated in García-Ramos et al. (2002). During recent years some Cameros Basin outcrops have also yielded pterosaur bones. Fuentes \& Meijide Calvo (1996) cited the first one from Soria province. Later, Moratalla et al. (2001) reported some scattered bone fragments from the Sol de la Pita 1 fossil site (Préjano, La Rioja province), and also some relatively well preserved bones from the Fuente Amarga locality (also at Préjano township) (Pérez-Lorente et al., 2001). Both pterosaur sites belong to the Leza Fm. (Enciso Group, Lower Aptian in age). In contrast to this relatively scarce pterosaur bone fossil record, the paleoichnological pterosaur material is notably abundant. The first pterosaurian interpretation of these Cameros tracks was provided by Lockley et al. (1995), stressing limb posture, locomotion and distribution of this group of archosaurs. After that Meijide Calvo \& Fuentes (1999) described some pterosaur tracks from Soria province and Pascual \& Sanz (2000) described abundant pterosaur prints from the Oncala Group (mainly Huérteles Alloformation) also in Soria province. These last authors stressed on the presence of at least 17 tracksites with pterosaur foot and manus prints. So, the pterosaur tracks we describe herein are, until now, the only ones from the Enciso Group (Lower Aptian).

The aim of this paper is to describe and to interpret both the turtle and pterosaur tracks from the Los Cayos 
locality, stressing the morphology and paleo-ecological significance. Also we review the evidence of other Cameros remains to explore the implication of the pterosaur tracks for understanding terrestrial locomotion and ecology.

\section{GEOLOGICAL SETTING}

The Cameros Basin is located in the north-westernmost part of the Iberian Range outcropping in the Spanish provinces of Burgos, Soria and La Rioja, and covering an area of about $8000 \mathrm{Km}^{2}$.

Nowadays, the basin is a fold-and-thrust belt inverted during the Paleogene and early-middle Miocene (called the Cameros Massif or Unit), overthrusting the nearby Tertiary basins: the northern Ebro Basin, the southern Almazán Basin and the western Duero Basin. The Paleozoic Demanda Massif also outcrops toward the north and overthrusts the Cameros Unit (Fig. 1a).

During the latest Jurassic and early Cretaceous, the Iberian Plate was in a highly extensive context related to the opening of the Bay of Biscay and the North Atlantic (Malod \& Mauffret, 1990). This extensive regime gave rise to numerous Rift Systems developed mostly into the paleomargins of the Iberian Plate: the northern Iberian Margin (Peybernès, 1982; Vergés \& García-Senz, 2001), the southern Iberian Margin (Vera, 2001) and the western Iberian Margin (Pinheiro et al., 1996; Alves et al., 2006). Moreover, the Mesozoic Iberian Rift System (MIRS) was developed in a more intraplate position which resulted in the creation of an intricate collection of rift basins and sub-basins: Maestrazgo, South Iberian, Cameros and Columbretes (Salas et al., 2001). The Cameros Basin is one of the most remarkable because it represents an atypical sedimentary record among the MIRS basins due to its insignificant marine influence, and its high subsidence and sedimentation rates (Mas et al., 1993). Moreover, it is also the only one in which a low- to very low-grade metamorphic events took place in part of the infill (Barrenechea et al., 1995, 2001; Alonso et al., 1995). Lastly, this basin also exhibited an unusual structural style with no main border faults, being interpreted as an extensional-ramp basin produced over a south-dipping ramp over a basement-involved and deep-horizontal fault (Mas et al., 1993; Guimerà et al., 1995).

The Cameros Basin (Fig. 1b) can be subdivided into two sub-basins with a quite distinct palaeogeographical, tectonic and stratigraphical settling, and termed Western and Eastern Cameros (Mas et al., 1993; Arribas et al., 2003; Salas et al., 2001). The Eastern Cameros sub-basin exhibits an exceptional sedimentary pile of deposits in the depocentral area (up to 9000-m-thick) with an impressive richness in vertebrate-track-bearing sites, mainly dinosaurdominated ichnofaunas and to a lesser extent pterosaur-, bird- and turtle-footprints (Moratalla et al., 1997; Sanz et al., 1997) and rare bones. On the other hand, the Western Cameros sub-basin, up to $3000 \mathrm{~m}$-thick, contains abundant skeletal remains and less tracksites (Torcida, 1996, 2006).

The synrift-depositional infill consists of continental sediments deposited in alluvial and/or lacustrine systems with only minor marine incursions. The first scheme developed in the Cameros Basin identifies five lithostratigraphical Groups (Tera, Oncala, Urbión, Enciso and Oliván), which are reliable for ease of use and utility in the field (Tischer 1966a, 1966b; Beuther, 1966) (Fig. 2). Nevertheless, at the present time, the stratigraphical scheme is based on depositional sequences comprising a latest Jurassic-early Cretaceous megasequence limited by two major unconformities of regional extent at the base and the top (Tithonian and early Albian respectively). This synrift megasequence can be further subdivided into eight unconformity-bounded depositional sequences. Each sequence displays an arrangement beginning at the base with siliciclastic-alluvial deposits which are overlain by carbonate-lacustrine deposits (Fig. 2) (Salas et al., 2001; Mas et al., 2002, 2003).

\section{LOS CAYOS TRACKSITE: SEDIMENTOLOGICAL OVERVIEW}

The Los Cayos tracksite is located in the Enciso Group (late Barremian-early Aptian) depositional sequence 7 (Fig. 1c). The Enciso Group, up to 1400 -m-thick, was deposited only in the Eastern Cameros sub-basin and consists predominantly of siliciclastic- and/or carbonate-dominated lacustrine and meandering-fluvial systems (Mas et al., 2002, 2003; Doublet et al., 2003). In the study area, the sedimentary record comprises a meter-cyclical alternation of siliciclastic and carbonate sequences marked by strong lateral facies changes (Moratalla et al., 2003).

The siliciclastic sequences are composed of lutite-dominated tabular bodies with some horizontal- to cross-bedded sandstones packages, sometimes displaying an evident upward-coarsening trend. The lutite units comprise mottledstructureless non-graded siltstones with intense to moderate bioturbation, and parallel- to ripple-laminated organic-rich siltstones and minor claystones (occasionally sandy) with moderate to sparse bioturbation. Some beds are topped by mudcracks and symmetrical ripples. The sandstone units consist of medium to fine-grained micaceous quartzarenites and (sub)arkoses. Massive bedding and horizontal lamination predominate with rare cross-stratification. Mottling, moderate to intense bioturbation, mudcracks and ripples are common. The subordinate sheet-like and ribbon sandstone bodies represent the clastic supply deposited by traction currents, and interpreted as sheetfloods, crevasse splays and/or channel-mouth bars. The lutites characterize the fine-grained fraction deposited by fallout in interchannel lows, in-channel or adjacent standing-water bodies (Smith et al., 1989; Tye \& Coleman 1989a, 1989b; Smith \& Pérez-Arlucea, 1994; Pérez-Arlucea \& Smith, 1999). 
a
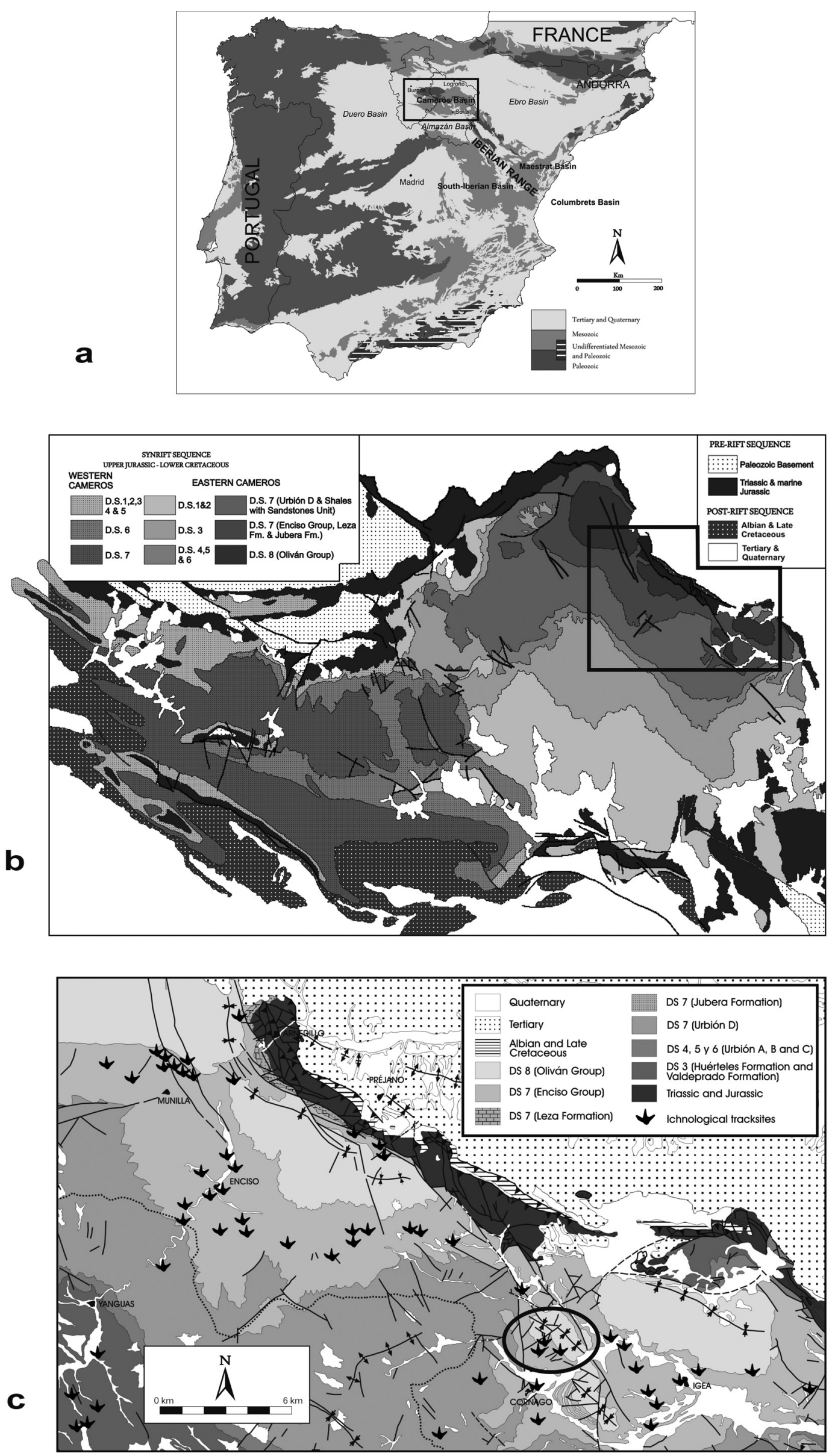


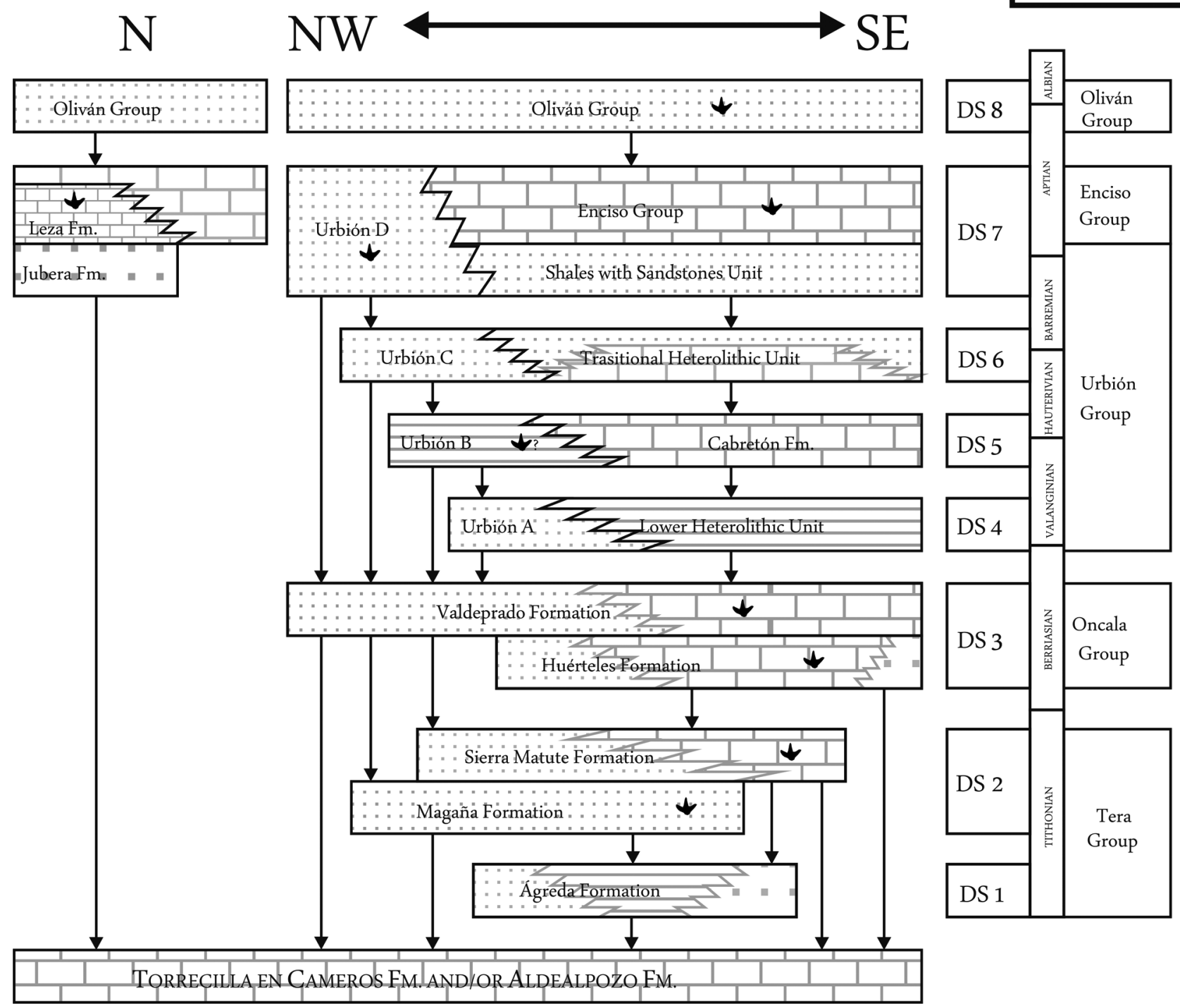

Figure 2. Stratigraphic framework of the Eastern Cameros sub-basin.

The carbonate sequences comprise interbedded marlstones and limestones, with minor sandy and marly limestones. The limestone occurs as organic-rich dark-tabular micrite beds with minor terrigenous and diverse proportions of ostracod- and mollusc-shells. Massive (homogeneous and non-graded) or vaguely laminated mudstone and wackestone are the most common limestones, although nodular beds can occur also. Locally, mud-cracked and mottled beds can be very abundant. The low-degree of pedogenic development suggests weak reworking and short subaerial-exposure times. These units mainly represent low-energy and ramptype carbonate-lacustrine environments (Platt \& Wright, 1991) and, to a lesser extent, poorly developed palustrine, mudflat and wetland settings (Alonso-Zarza, 2003).

Figure 1. a, Location of the Cameros Basin. b, Geological map of the Cameros Basin. c, The Los Cayos area (Cornago, La Rioja province) is situated inside the circle in the lower map. The footprint marks represent the main dinosaur tracksites of the Enciso Group. 
To summarize, the study area is interpreted as deposited by north-eastward prograding-avulsion belts and lacustrine deltas/splays into the surrounding carbonate-lake system, developed during stages of non- to low-detrital input.

\section{TURTLE TRACKS: Emydiphus sp.}

Two layers with turtle tracks have been discovered at the Los Cayos locality: Los Cayos C and Los Cayos A described as follows:

\section{LOS CAYOS C OUTCROP}

The turtle track-bearing layer occurs at Los Cayos C (Cornago). It is a surface of about $13 \mathrm{~m}^{2}$ of a very fine green siltstone. The outcrop shows 16 dinosaur footprints, although some of them do not indicate good preservation. The best-preserved specimens, forming a trackway (Fig. 3), are tridactyl in shape, with elongated digit impressions, parallel digital outlines, distal ends not too sharp, conspicuous pad impressions, and a relatively high length/width relationship (1.26). Moratalla (1993) named this type of tracks Therangospodus. A revision of this ichnogenus throughout the Jurassic-Cretaceous boundary was carried out by Lockley et al. (1998), stressing on the wide extended presence of this kind of "narrow-foot" theropod trackmaker.

58 turtle tracks have been mapped at this outcrop (Fig. 3b). Although most of the tracks are isolated, one can observe several alignments suggesting some kind of direction of movement. The tracks are about $0.5-1.5 \mathrm{~cm}$ in length, and consist of parallel isolated digit impressions. These digital prints show acuminate distal ends and relatively blunt proximal margins. The digits are not connected in the proximal zone. Most of the tracks show three digits, although some have only two or even only one digit trace. Although the digits show a general welldefined straight shape, most of them are slightly curved, sometimes with only the external digit or alternatively two or all of them curved (Fig. 4). The central digit is normally the longest one. However, sometimes one of the external digits could be about the same length as the central one. The separation of the digits is sometimes regular, that is, the distance is more or less the same between the central one and the other external digits. But the normal disposition shows a different separation between the two margins of the track. This fact is responsible for the asymmetric aspect of these tiny prints. The areas between the

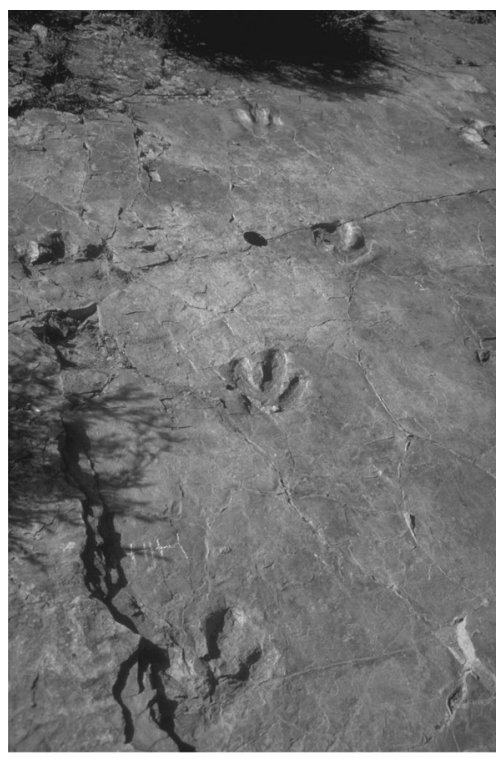

a

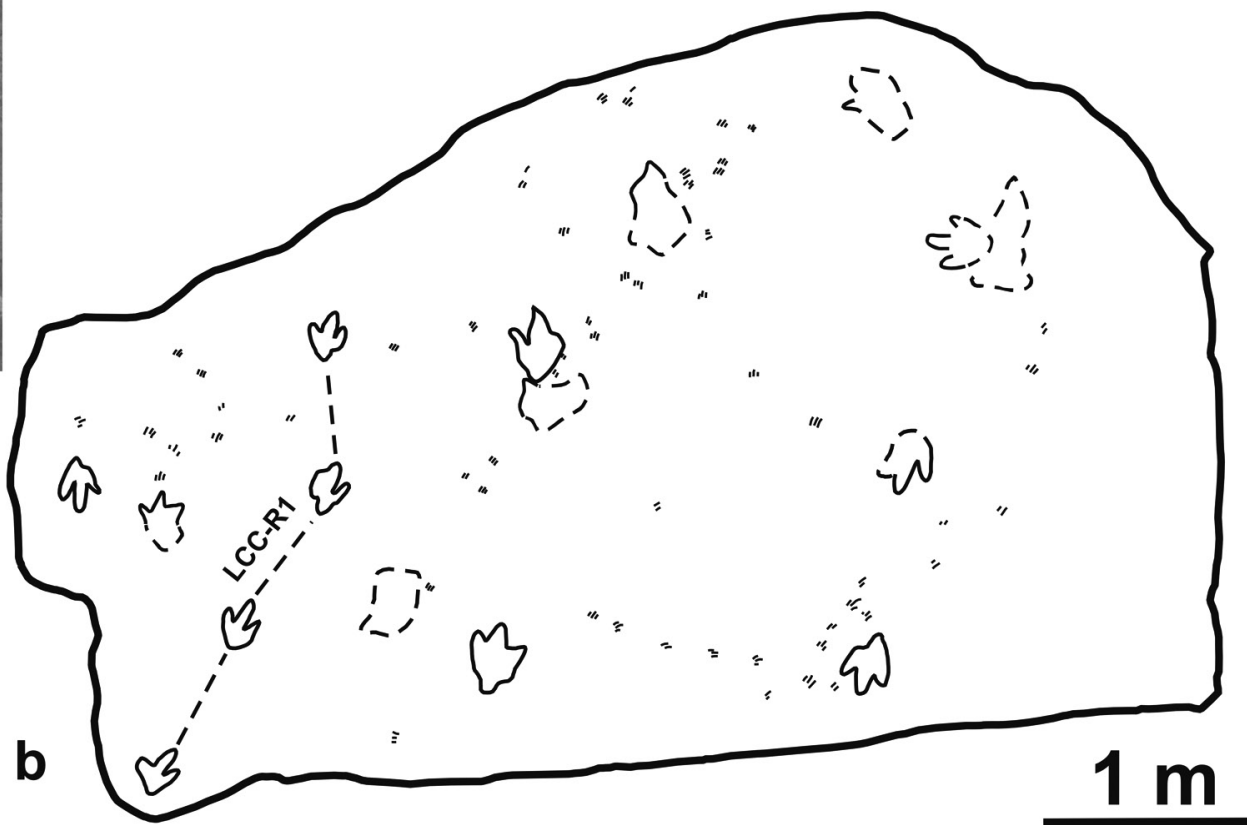

Figure 3. Los Cayos C (Cornago, La Rioja province). a, photograph of the dinosaur trackway LCC-R1. b, map of the level with dinosaur and turtle tracks. 
digits are relatively smooth, that is, no impressions suggesting the presence of an interdigital web can be observed. The track alignments suggest some kind of direction of movement, and although they do not show a regular pattern the alignment suggests that they were produced by the same animal progressing on the substrate (Fig. 5).

\section{LOS CAYOS A OUTCROP}

A little slab of about $1 \mathrm{~m}^{2}$ shows several tiny prints shown in figure 6. The size, shape and general morphology of these tracks are similar to those described from Los Cayos C. Only some differences could be pointed out, although they are probably more derived from preservation or substrate conditions. The most outstanding feature of the Los Cayos A turtle prints is that two of the tracks show the impression of 5 digits (Fig. 6). Although most of the digits show a relatively straight shape, some of them are slightly curved. Distal ends are mostly acuminate while proximal ends are, on the contrary, broadly expanded. No trackway pattern can be observed on the slab. However, most of the tracks are arranged in a similar direction suggesting that they could have been produced by the same trackmaker.

\section{DISCUSSION OF TURTLE TRACKS}

Similar material to that described from Los Cayos and interpreted as turtle tracks, is relatively scarce in the Mesozoic fossil record (Fig. 7). The first finding was cited at Cerin (France) (Bernier et al., 1982, 1984). Although at first some of them were interpreted as produced by a "ricochet" pattern of locomotion caused by a hopping dinosaur, the morphology, size, and trackway disposition suggests the possible turtle origin (Thulborn, 1989). After the description by Moratalla (1990) of an isolated possible turtle track from Los Cayos A, and also a description of the slab we are studying here in the PhD Thesis by Moratalla (1993), few possible Mesozoic turtle tracks have been discovered from: the Morrison Fm. of Copper Canyon in Southern Utah (USA) (Foster et al., 1999) (Fig. 7a), the Laramie/Arapahoe Fm. (Upper Cretaceous of Colorado) (Wright \& Lockley, 2001) (Fig. 7b), the Upper Jurassic of Asturias coast (García Ramos et al., 2002), a trackway from the Cameros Basin (Fuentes et al., 2003b) (Fig. 7d), another turtle trackway from Cerin
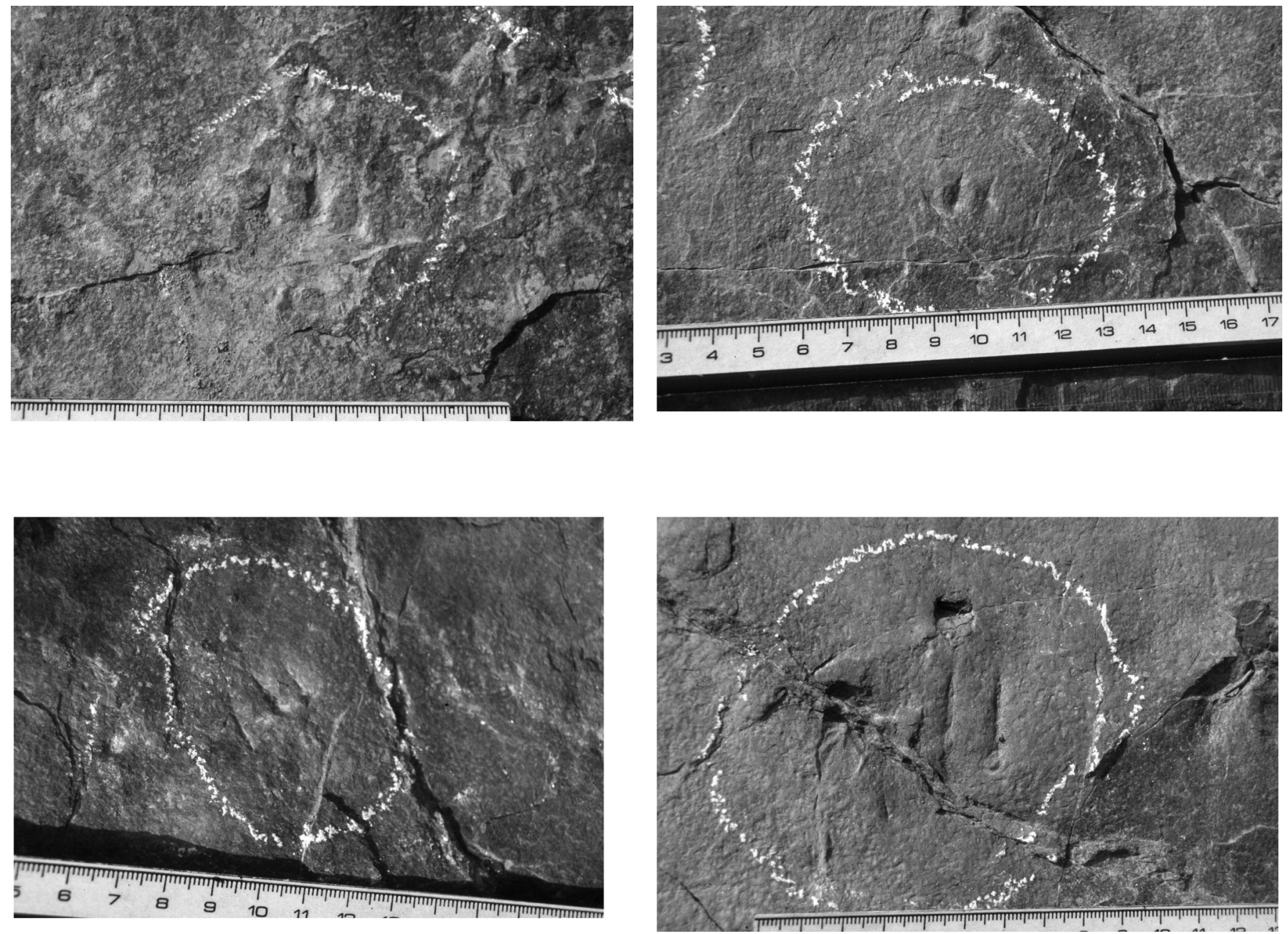

Figure 4. Some examples of isolated turtle tracks from the Los Cayos C tracksite (Cornago, La Rioja province). 


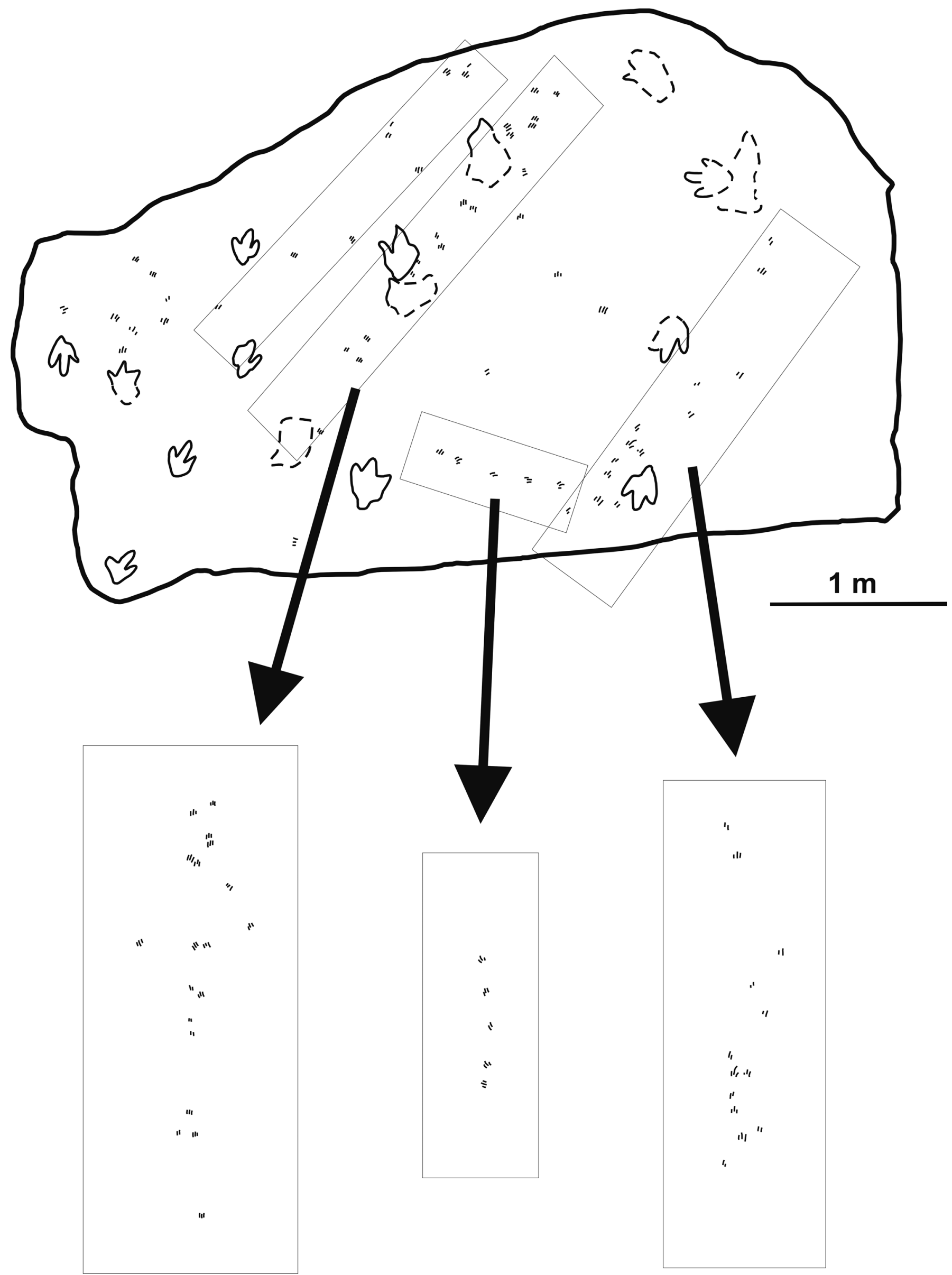


(France) (Gaillard et al., 2003) (Fig. 7e) or relatively large turtles tracks from the Upper Cretaceous of Montana (Fiorillo, 2005), tracks from Soria province (Fuentes et al., 2008), from Croatia (Mezga \& Bajraktarevic, 2004) and Colorado (USA) (Lockley et al., 2006; Lockley \& Foster, 2006).

The Copper Canyon tracks (Fig. 7a) are relatively similar to those from Los Cayos C. These similarities can be stressed based on tridactyl morphology, general size, and trackway or alignment configuration. However, some differences could be pointed out. Some of the Copper Canyon prints show a tetradactyl form, and also, the proximal margin of the digits are connected by the rear outline of the print, showing a "heel-like" morphology. Wright \& Lockley (2001) stressed the similarities between this Utah-material and the turtle tracks described from the Upper Cretaceous of Colorado (Fig. 7b). In this last case, the tracks are shorter and wider, with 4-5 claw marks in a shallow depression. However, there are also tridactyl prints formed by isolated digit marks. A relatively well preserved turtle trackway has been described from Cerin (France) (Gaillard et al., 2003) (Fig. 7e). These tracks, interpreted as produced by a marine turtle, show significant differences with the Los Cayos prints related to print size, shape, and general morphology. Fiorillo (2005) describes a set of rounded turtle prints made probably by a relatively big animal on wet sediment. The tracks are deep, relatively rounded in shape, and without digit impressions. The differences between these Montana turtle tracks and those from the Los Cayos locality we describe herein, suggest that the size and morphology of the trackmaker, and probably the locomotion and sediment conditions were also quite different.

Some turtle tracks described by García Ramos et al. (2002) and Avanzini et al. (2005) from the Upper Jurassic of Asturias region (north Spain), show several similarities with the Los Cayos tracks described herein. These similarities are based on the general tridactyl track morphology, the presence of parallel digit marks, and the relative curved shape of the external digital impressions. On the contrary, the Asturian tracks are bigger, about 5-8 $\mathrm{cm}$ in length. The turtle trackway discovered in Valduérteles locality (Soria province) provides good material for comparison (Fig. 7d) (Fuentes et al., 2003b). The trackway consists of a series of 14 manus-pes sets. While the pes prints are tetradactyl with a heel-like rear area, the manus tracks are formed by three or four isolated digital impressions. These digital marks show a sub-parallel disposition without a clear heel zone. The shape, size, and general disposition of these manus prints are relative similar to those of the Los Cayos $\mathrm{C}$ turtle tracks we describe herein. Although Fuentes et al. (2003b) named the Valduérteles trackway Emydhipus, neither consistent comparison with similar fossil prints or with the osteological record has been made. Most of the diagnostic features proposed for Emydhipus are based on general trackway pattern and track morphology. The authors have identified this trackway as an "aquatic turtle"; but no more precise explanation about the "aquatic" term or taxa comparison was made. Based on the high similarity between the Los Cayos C prints and the Valduérteles trackway, we conclude that both print assemblages were made by a similar kind of trackmaker and, so, the turtle tracks from Los Cayos locality can be ascribed to the ichnotaxon Emydhipus.

The phalangeal formula of the turtles is 2-2-2-2-2 for Proganochelis and 2-3-3-3-3 for the modern turtles (Carroll, 1988). The support of the autopodia on the substrate is in some way digitigrade for the manus and plantigrade for the feet. The lateral orientation of the manus during the locomotion could have resulted in the registration of only three or four digits (Bernier et al., 1982). If we consider that the Los Cayos C prints are mainly scrape marks, probably produced during buoyant activities (swimming or floating), the support of the autopodia would have been incomplete. This consideration is consistent with the absence of complete tracks and also with the presence of isolated digital impressions. So, the morphology of these prints does not allow a more precise identification based on Lower Cretaceous turtle groups (Jiménez, 1987, 1995; Jiménez et al., 1990) known from skeletal remains. In any case, the Los Cayos C outcrop is a good case of dinosaur and turtle track association on the same sedimentary level. This fact suggests that both groups, mainly the dinosaurs, were relative abundant on these Lower Cretaceous landscapes, sharing the riverbanks and the margins of the small lakes where water was shallow and the substrate sometimes emergent. Future findings of both bones and tracks could provide new insights to help complete the framework of the Lower Cretaceous bio-diversity from the Cameros Basin.

\section{PTEROSAUR TRACKS: Pteraichnus sp.}

Both the Los Cayos A and C outcrops have yielded isolated pterosaur manus prints (Fig. 8). The pterosaur tracks at Los Cayos A occur on a slab fragment of about $75 \mathrm{~cm}^{2}$. The slab is located in situ about $1 \mathrm{~m}$ below the main Los Cayos A dinosaur track-bearing layer. It consists of very fine sandstone. The slab contains 4 tracks. They are between 5-6 cm in maximum dimension (Fig. 8a). Specimen LCA-PT04 shows only the impression of the central digit, and LCA-PT01 is altered by a small fracture making it difficult to see its three-dimensional form. The prints are shallow, about $0.5 \mathrm{~cm}$ deep, and tridactyl. The digits show blunt distal ends and high interdigital angles. The angle between the two lateral digits ranges between $65^{\circ}$ and $135^{\circ}$. The

Figure 5. Map of the outcrop with turtle tracks from the Los Cayos C (Cornago, La Rioja province), showing some sequences of prints attributed to progression of individuals in recognizable directions. 


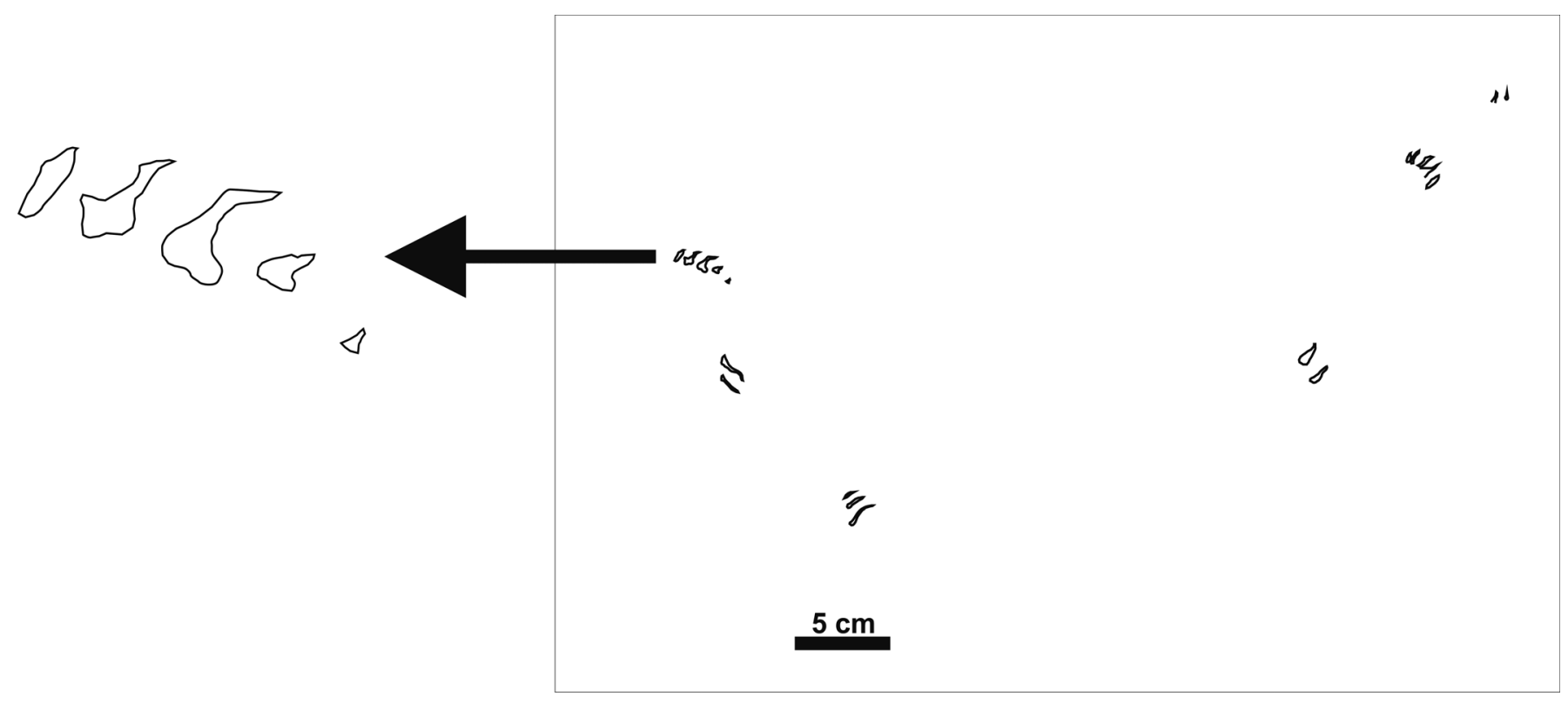

Figure 6. Turtle tracks from Los Cayos A (Cornago, La Rioja province) with enlarged detail of pentadactyl track (left).

tracks are clearly asymmetrical, with the medial digit the shortest one. The most elongated digit (the lateral one or digit III) is about $13 \%$ longer than the central one. The proximal track area shows a very broad and rounded outline. The different orientation of the tracks suggests that they do not belong to a single trackway, with a definable direction of movement.

Los Cayos C has yielded only an isolated pterosaur manus impression (Fig. 8b). Although this print is more or less similar to those seen previously, some differences include digit I showing a blunt distal end, the central and the external digits being deeper and showing conspicuous acuminate distal impressions. The central digit is relatively straight and V-shaped at the distal end whereas digit III shows a slight curve with a lateral orientation. The length of digits I and II is relatively similar. The angle between digit II and III is significantly narrower $\left(39^{\circ}\right)$ than the angle between digit I and II $\left(92^{\circ}\right)$ : that is, the central digit is mostly oriented toward the external digit impression.

The general morphology of these tracks, with digit I (see the Fig. 8b) the shortest and digit III the longest, and the angulation between I-III digits suggest that these Los Cayos prints can be ascribed to the ichnogenus Pteraichnus proposed by Stokes (1957). Although the name was proposed based on pterosaurian identification, not all the authors agree with this proposal (Padian \& Olsen, 1984). However, recent works seem to stress on its pterosaurian affinity (Kubo, 2008).

Although the ichnocoenosis of the Cameros Basin is clearly dominated by dinosaur tracks, it has also yielded other pterosaur ichnofossils. They are mainly located in
Soria province within the Oncala Group (Tithonian-Berriasian in age). Pascual \& Sanz (2000) reported up to 17 pterosaur track localities, most of them belonging to the Huérteles Alloformation. Most of the localities are clearly dominated by pterosaur manus prints. In fact, only one tracksite (Los Tormos, Santa Cruz de Yanguas township) has yielded three pterosaur trackways (Fig. 9). These and other authors proposed diverse new Pteraichnus ichnospecies from these Oncala fossil sites: Pteraichnus palacieisaenzi Pascual \& Sanz, 2000, P. cidacoi Fuentes, 2001, $P$. manueli Meijide Calvo, 2001, and $P$. vetustior Meijide Fuentes, 2001. Due to the absence of an adequate ichnospecies diagnosis and also an adequate indication of holotype location or even a holotype designation, we conclude, according to Billon-Bruyat \& Mazin (2003), that all these Spanish Oncala ichnospecies are invalid and should be considered as nomina nuda.

Figure 10 represents a comparison between the material we study herein and other pterosaur ichnofossils. Some differences could be pointed out. Both Los Cayos A and $\mathrm{C}$ prints show a bigger angle between digits I and II $\left(92^{\circ}\right.$ for LCC-PT1 and $74^{\circ}$ for LCA-PT01). By contrast, the mean value for this angle in the Soria material ranges between $39.22^{\circ}$ and $43.9^{\circ}$. Only tracks from level VII of the Valdelavilla outcrop show a mean angular value of $81.4^{\circ}$ (Pascual \& Sanz, 2000). These values can be compared with the Pteraichnus material from other parts of the fos-

Figure 7. Prints attributed to turtles from the fossil record. a, turtle tracks from the Copper Canyon site (after Foster et al., 1999). b, turtle tracks from Leydon Gulch locality (after Wright \& Lockley, 2001). c, some of the turtle Los Cayos C specimens. d, turtle trackway from Valduérteles locality (Soria province) named Emydhipus by Fuentes et al. (2003b). e, Turtle trackway from Cerin (France) (after Gaillard et al., 2003). 


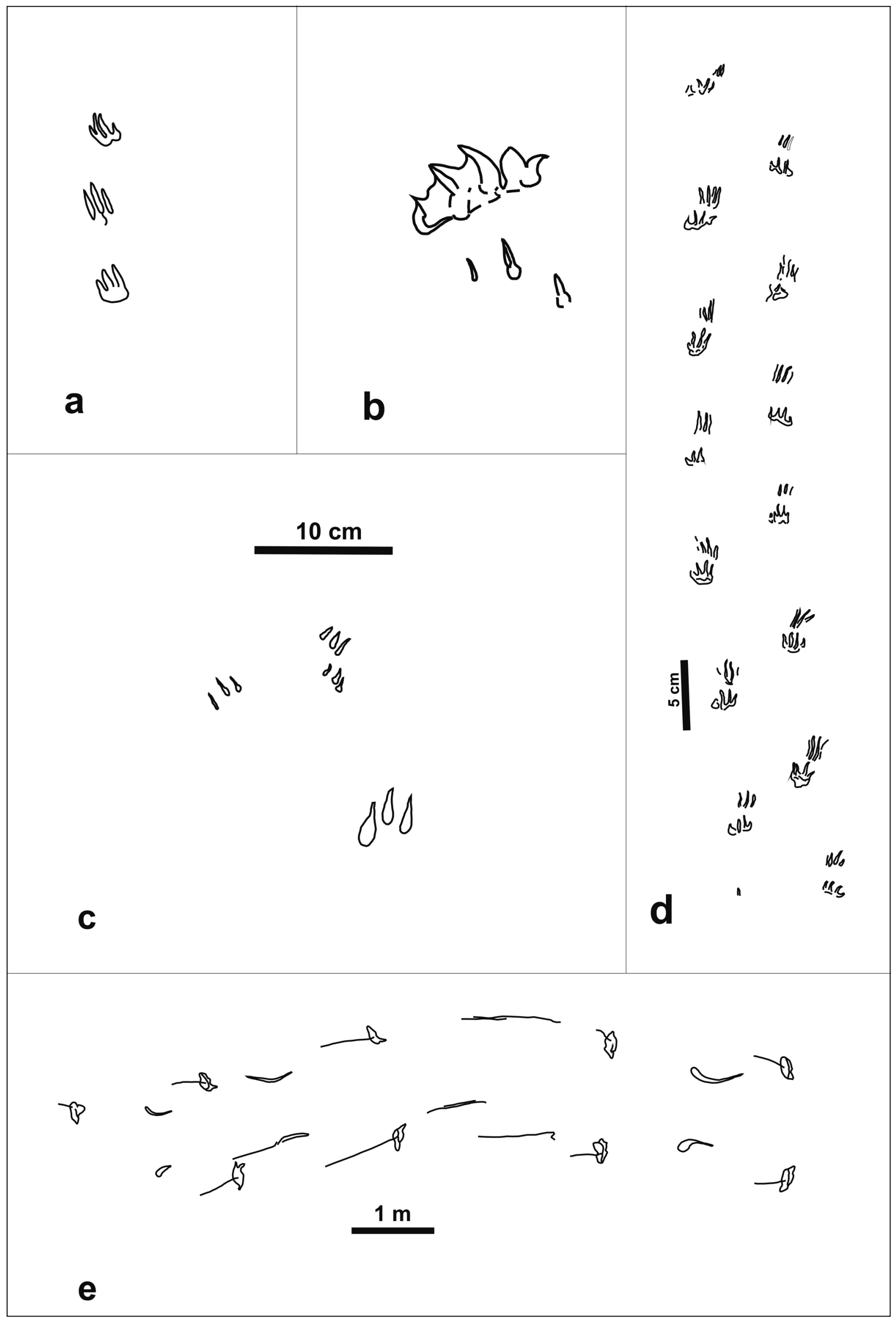



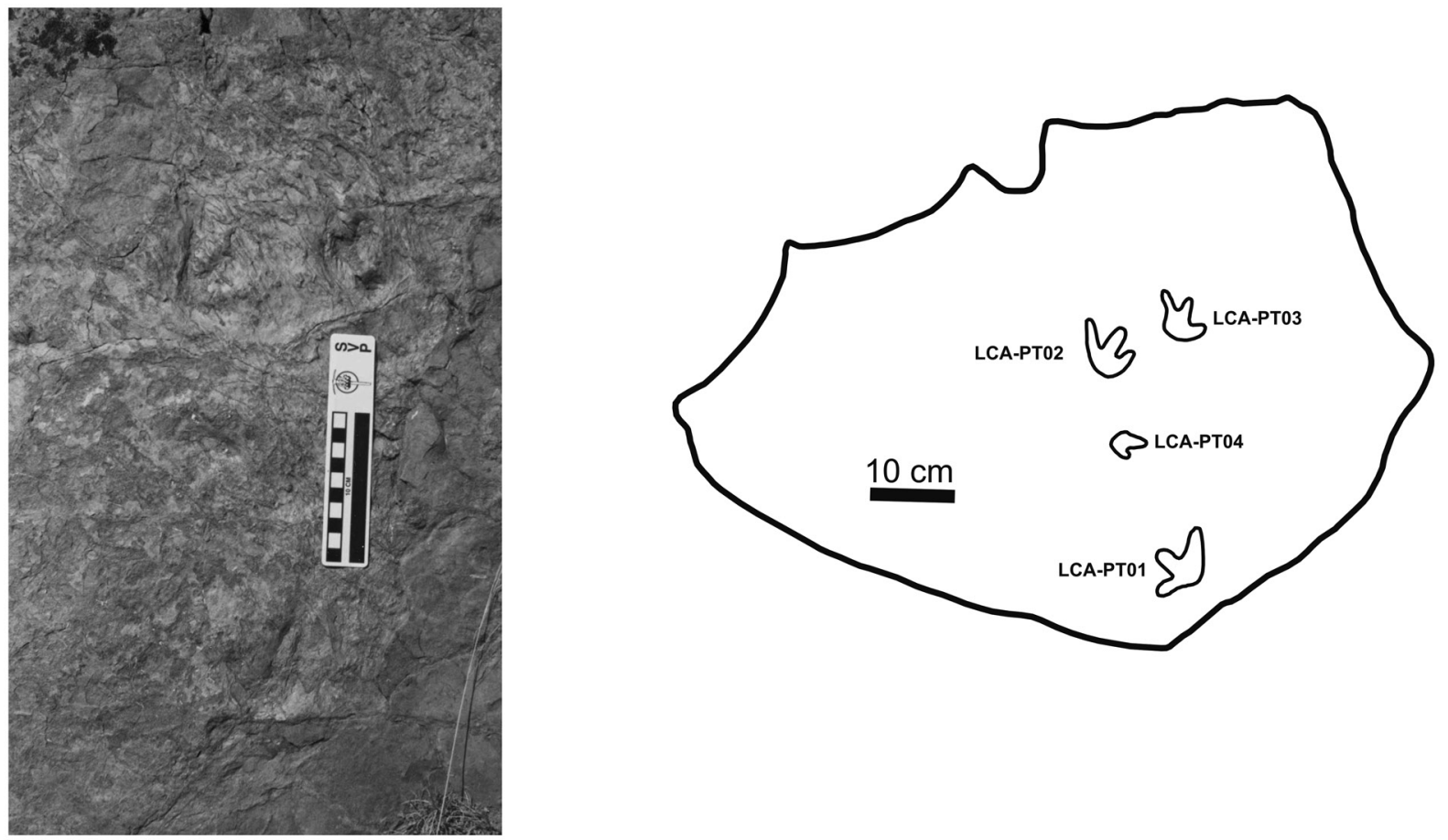

a
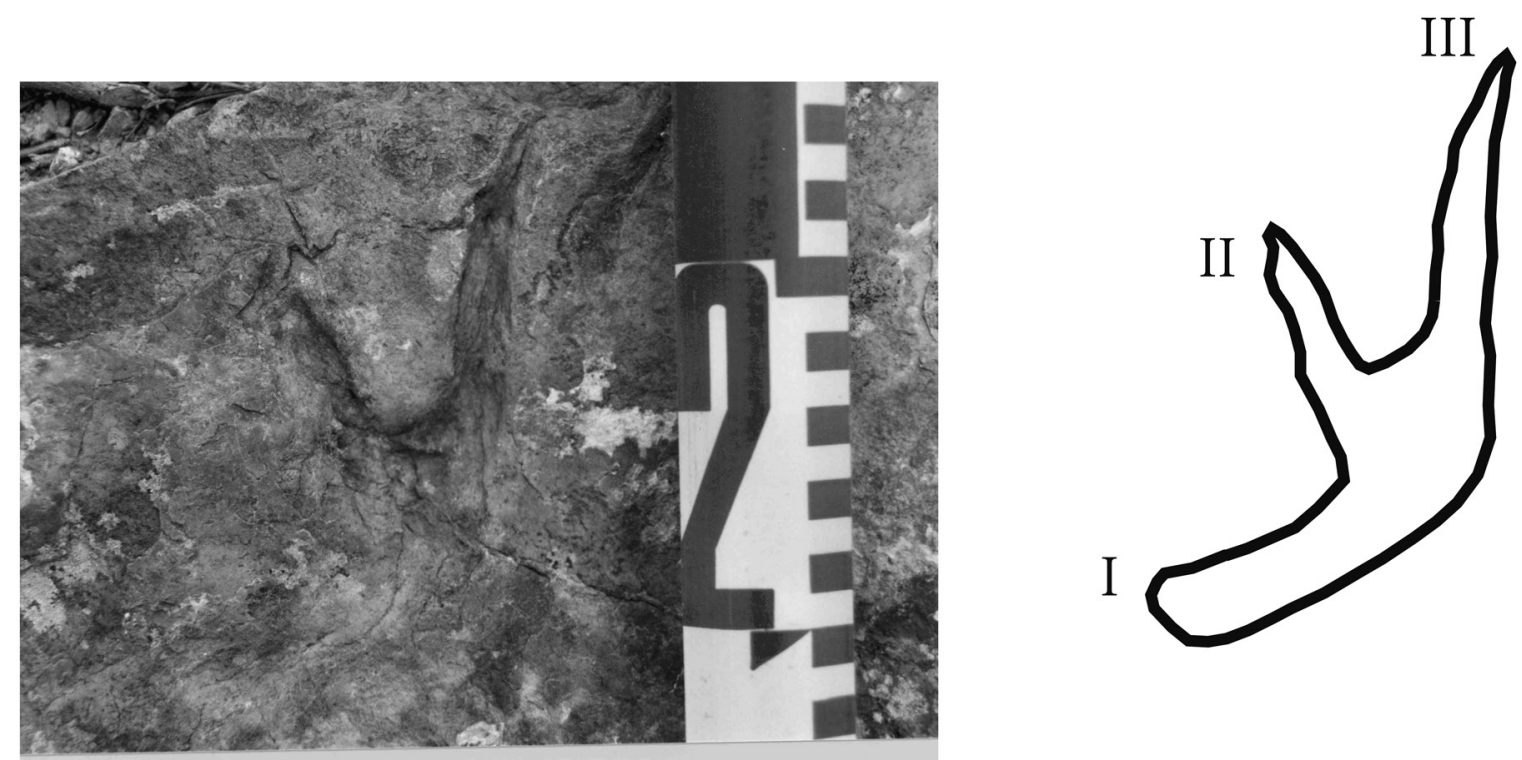

$10 \mathrm{~cm}$

b

Figure 8. Pterosaur manus prints from the Los Cayos tracksite (Cornago, La Rioja province). a, photograph and map of the slab at Los Cayos A. b, photo and print drawing of LCC-PT1. 


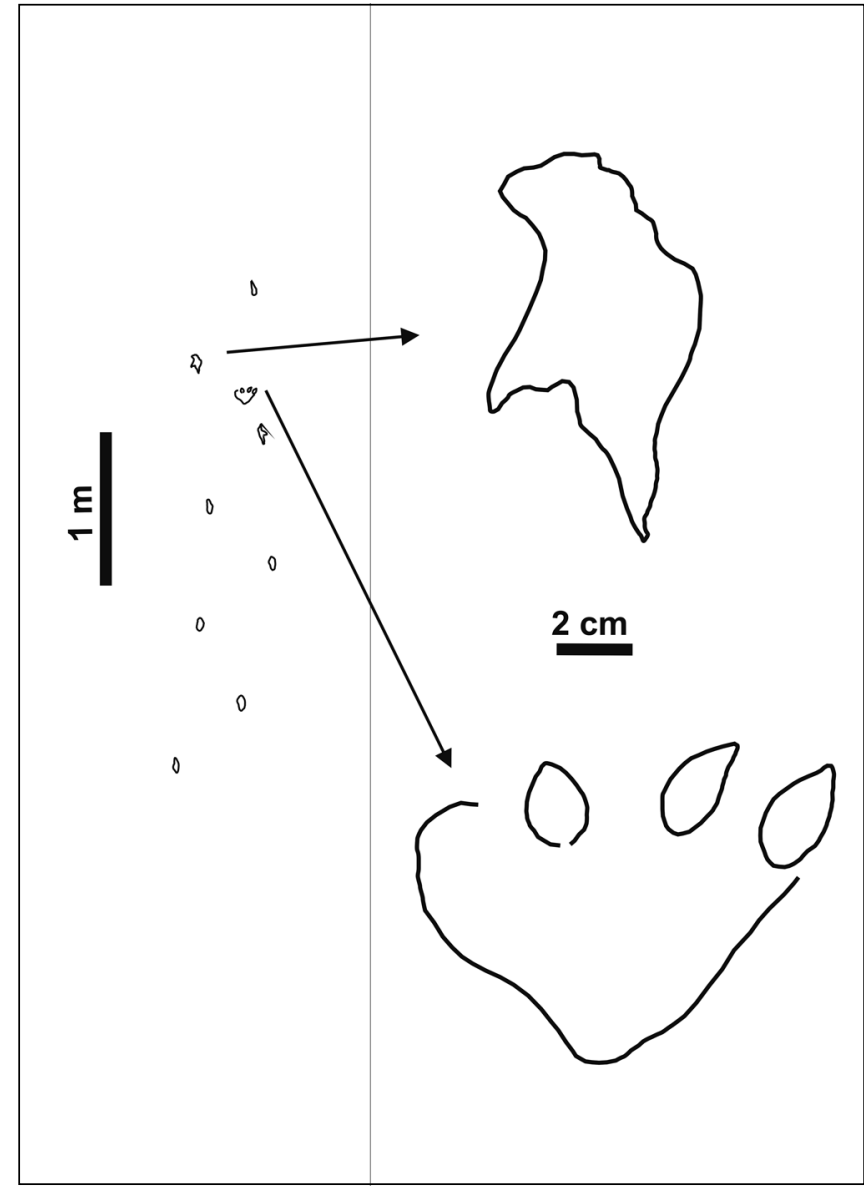

Figure 9. Lower Cretaceous pterosaur trackway from the Los Tormos tracksite (Santa Cruz de Yanguas, Soria province) described by Moratalla (1993) and Lockley et al. (1995).

sil record. So, this angle for Pteraichnus stokesi, from the Sundance Formation, is about $20^{\circ}$, while for $P$. saltwashensis from the Summerville Formation is about $31^{\circ}$. Purbeckopus Delair, 1963, a pterosaur track morphotype from the Lower Cretaceous of Dorset (England) shows a low I-II angle, about $19-20^{\circ}$ (Wright et al., 1997). This angle is about $65^{\circ}$ in the Pteraichnus-like manus prints from the North Horn Formation in Utah (Lockley, 1999). The same case occurs with the Pteraichnus tracks from Furnish Canyon (Colorado), with the angles measuring about $60-70^{\circ}$ (Lockley et al., 2001) (Fig. 11).

Although the Los Cayos pterosaur prints are morphologically similar to those described in the literature cited, the relatively high value for the I-II angle seems to be significant. The question is if this high angle depends on anatomical hand construction or on the stance on the substrate. Mazin et al. (1995) suggests that the relatively shortness of digit I is caused by a curved disposition of this digit during the step. This curvature could have two interesting consequences: 1) the short dimension of the digit I print, and 2) its external orientation, that is, the low val- ue of the angle I-II. The pterosaur trackways show a low variation of the digit I-II angle, suggesting that the position of digit I during locomotion was relatively constant. This suggests that the differences among different pterosaur trackways could be caused by differences in anatomy. If this interpretation is correct, the morphology of the Los Cayos pterosaur manus prints could be caused by different pterosaurs than those from the Oncala Group. Taking into account that the Oncala Group is dated as TithonianBerriasian and the Enciso Group is considered as Lower Aptian, implying an interval of about 20 my, it would be possible to consider different pterosaur faunas for each geological Group. Unfortunately, the scarcity of pterosaur fossil tracks in the Enciso Group does not allow a more precise identification and comparison. Pérez-Lorente et al. (2001) have reported pterosaur bones from Préjano township (La Rioja) named Prejanopterus curvirrostra nomen nuda; however, there is not yet a formal description with an adequate list of characters in order to compare both the ichnological and the bone fossil records.

Despite the scarcity of pterosaur tracks in the Enciso Group, the whole Cameros fossil record has produced abundant pterosaur tracks during recent years. This fact suggests: 1) the pterosaurs had terrestrial locomotion capabilities more developed that we had though before, and 2) they were relatively common in the continental Cameros ecosystems like the dinosaurs, crocodiles, turtles, lizards, and several kinds of fluvial/lacustrine fishes.

Pterosaur terrestrial locomotion has been thoroughly debated in several papers, from the bipedal condition (Padian, 1983, 1984, 1985, 1987, 1988, 1991; Padian \& Rayner, 1993; Paul, 1987) to the quadrupedal gait (Pennycuick, 1986; Wellnhofer \& Vahldiek, 1986; Unwin, 1987, 1989, 1997; Wellnhofer, 1988, 1991; Lockley et al., 1995; Bennett, 1997; Mazin et al., 2003). Anatomical construction, arm and hand anatomy, the disposition of the fingers, limb proportions, and the center of gravity located near the scapular girdle suggest that the pterosaurs were obliged quadrupedal animals during terrestrial locomotion (Lockley et al., 1995). This quadrupedal gait is also suggested by the great abundance of manus prints rather than pes prints in the ichnological record. In contrast, a bipedal gait would have been very unstable, mainly due to the forward location of the center of gravity. Moreover, the relatively short body length implies a quadrupedal trackway with the pes tracks typically situated just anterior to the manus prints (Clark et al., 1998; Mazin et al., 2003; Li et al., 2006). Although the manus impressions are sometimes located well outside the pes prints, the pterosaur trackway evidence through the fossil record suggests that they were efficient ground walkers, with relatively constant stride lengths and a regular disposition of the tracks. Several pterosaur groups, such as the dsungaripteroids, seem to be well adapted for terrestrial locomotion (Unwin, 1997). 


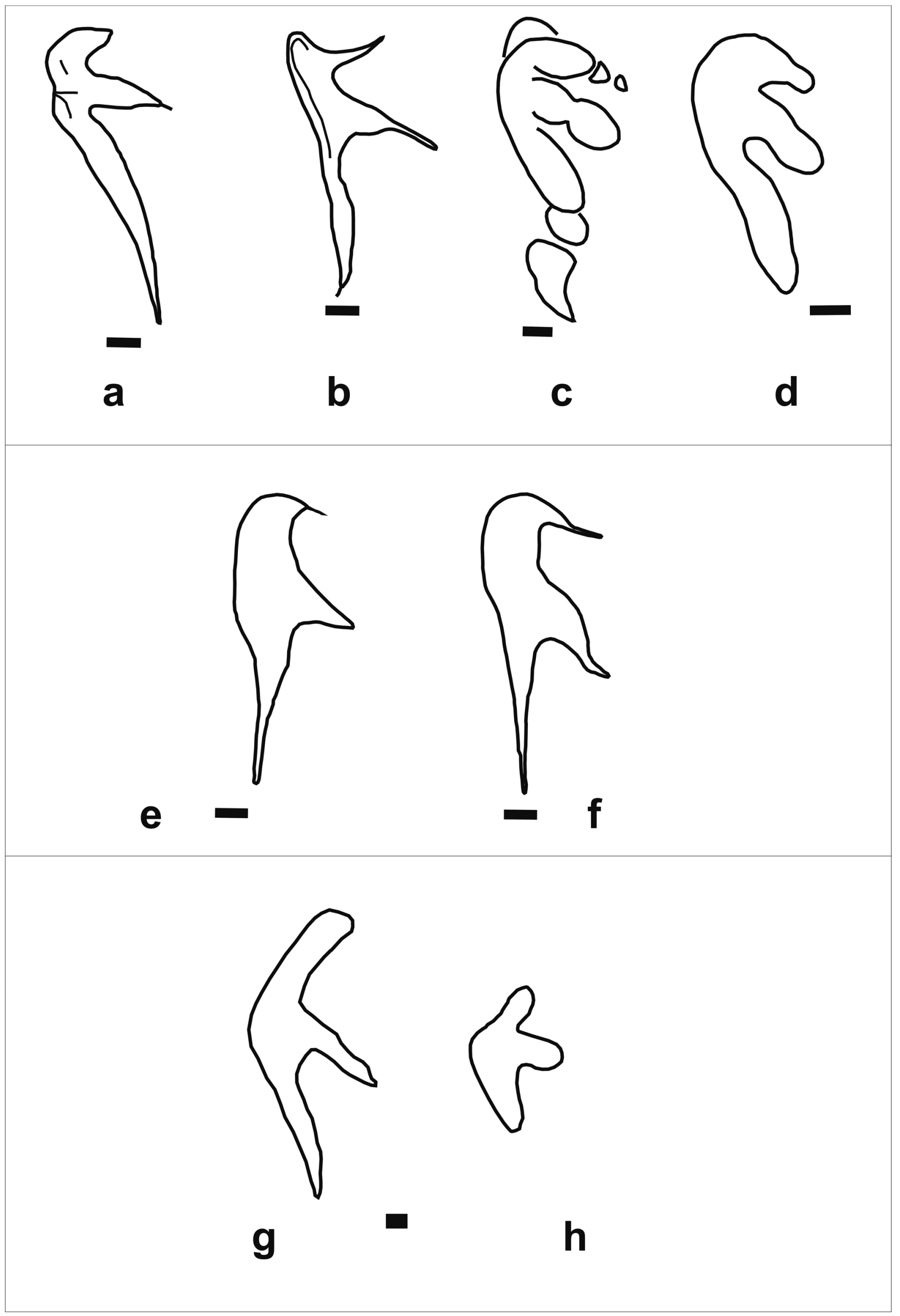


$\mathrm{LI} / \mathrm{Tw}$

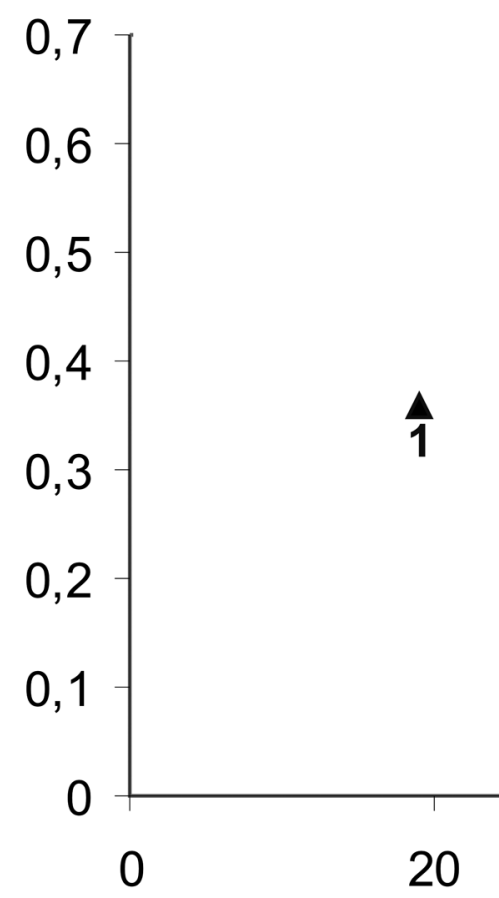

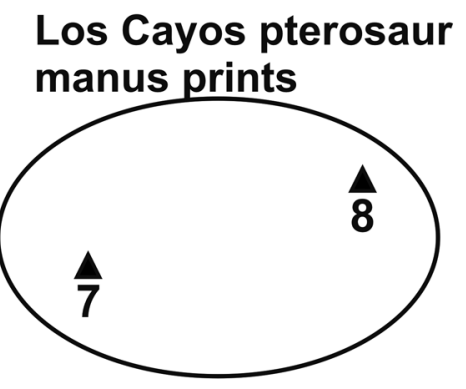

$\mathbf{6}$
24

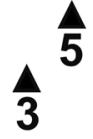

Figure 11. Bivariant analysis of a sample of pterosaur manus prints. Ang I-II, angle between the axis of digits I and II. LI/Tw, ratio between the length of the digit I and the print width. 1, Pteraichnus stokesi (after Lockley et al., 1995) (see Figure 9d). 2, Pteraichnus stokesi (after Bennet, 1997) (see Figure 10d). 3, Pteraichnus saltwashensis (Stokes, 1957) (see Figure 10a). 4, Pteraichnus sp. from Valdelavilla (Soria province) (after Pascual \& Sanz, 2000) (see Figure 10f). 5, Pteraichnus palaciei-saenzi from Santa Cruz de Yanguas (Soria province) (after Pascual \& Sanz, 2000) (see Figure 10e). 6, Pteraichnus cf. saltwashensis (after Lockley et al., 1995) (see Figure 10b). 7, LCA-PT01 from the Los Cayos A (Cornago, La Rioja province) (see Figure 10h). 8, LCC-PT1 from the Los Cayos C (Cornago, La Rioja province) (see Figure 10g). Note that the Los Cayos specimens show digit I relatively longer and higher I-II angle.

The Cameros Basin sediments represent, at least for the Oncala and Enciso Groups, fluvial-lacustrine environments with abundant fishes and other aquatic vertebrates and invertebrates. These paleo-environments were probably suitable for the pterosaurs as living habitats particularly for fish-eating pterosaurs such as several Lower Cretaceous European genera like Doratorhynchus Seeley, 1875, Criorhynchus Owen, 1874, Ornithodesmus Seeley, 1887, and even Prejanopterus nomen nuda from the Cameros itself. This was most likely the role of the pterosaurs in the Lower Cretaceous trophic chains and, some species could have played an important role in the dissemination of phanerogam seeds, and, in consequence, also in the evolution and diversification of these plants during the Cretaceous (Wellnhofer, 1991).

Future pterosaur findings will be necessary in order to understand their bio-diversity, their locomotion, their reproduction habits, and also their precise role in the $\mathrm{Ca}$ meros Basin ecosystems.

\section{CONCLUSIONS}

The discovery of pterosaur, turtle and dinosaur tracks on the same sedimentary levels suggests that these reptiles were significant components of the ancient fluvial-lacustrine ecosystem of the Los Cayos fossil site.

Figure 10.Pterosaur manus prints. a, Pteraichnus saltwashensis (Stokes, 1957). b, Pteraichnus cf. saltwashensis (after Lockley et al., 1995). c, Pteraichnus stokesi (after Bennet, 1997). d, Pteraichnus stokesi (after Lockley et al., 1995). e, Pteraichnus palaciei-saenzi from Santa Cruz de Yanguas (Soria province) (after Pascual \& Sanz, 2000). f, Pteraichnus sp. from Valdelavilla (Soria province) (after Pascual \& Sanz, 2000). g, pterosaur track from the Los Cayos C (Cornago, La Rioja province) (LCC-PT1). h, pterosaur track from the Los Cayos A (Cornago, La Rioja province) ( LCA-PT01). Scale, $1 \mathrm{~cm}$. 
The turtle tracks from both Los Cayos A and C are identified as Emydhipus sp.

The pterosaur tracks from Los Cayos A and C are identified as Pteraichnus sp. They comprise only hand prints with a relatively high angle between the digits I and II.

Both turtle and pterosaur prints represent the first find of these type of tracks in the Enciso Group of the Cameros Basin.

\section{ACKNOWLEDGMENTS}

We wish to thank Mr. Santiago Jiménez, director of the Museo de Ciencias Naturales of Arnedo (La Rioja) for his help in the field work and also to many volunteers from several amateur associations from Préjano, Cornago and Arnedo towns (La Rioja).

This paper was supported by the project CGL2006-10380 of the Spanish Ministry of Science in order to study the Lower Cretaceous bio-diversity.

We wish to thank Martin G. Lockley and Matteo Belvedere for their comments, suggestions and the improvement of the text.

\section{REFERENCES}

Alonso-Zarza, A.M. 2003. Palaeoenvironmental significance of palustrine carbonates and calcretes in the geological record. Earth-Science Reviews, 60, 261-298.

Alonso, J., Barrenechea, J.F., Rodas, M. \& Mas, J.R. 1995. Comparative study of the transition between very lowgrade and low-grade metamorphism in siliciclastic and carbonate sediments: Early Cretaceous, Cameros Basin (Northern Spain). Clay Minerals, 30, 407-419.

Alves, T.M., Moita, C., Sandnes, F., Cunha, T., Monteiro, J.H. \& Pinheiro, L.M. 2006. Mesozoic-Cenozoic evolution of North Atlantic continental-slope basins: The Peniche basin, western Iberian margin. American Association of Petroleum Geologist Bulletin, 90, 31-60.

Arribas, J., Alonso, A., Mas, R., Tortosa, A., Rodas, M., Barrenechea, J.F., Alonso-Azcárate, J. \& Artigas, R. 2003. Sandstone petrography of continental depositional sequences of an intraplate rift basin: Western Cameros Basin (North Spain). Journal of Sedimentary Research, 73, 309-327.

Astibia, H., Buffetaut, E., Buscalioni, A.D., Cappetta, H., Corral, C., Estes, R., García-Garmilla, F., Jaeger, J.J., Jiménez, E., Le Loeuff, J., Mazin, J.M., Orue-Etxebarria, J., Pereda-Suberbiola, J., Powell, J.E., Rage, J.C., RodríguezLázaro, J., Sanz, J.L. \& Tong, H. 1990. The fossil vertebrates from Laño (Basque Country, Spain); new evidence on the composition and affinities of the Late Cretaceous continental faunas of Europe. Terra Nova, 2, 460-466.

Avanzini, M., García-Ramos, J.C., Lires, J., Menegon, M., Piñuela, L. \& Fernández, L.A. 2005. Turtle tracks from the Late Jurassic of Asturias, Spain. Acta Palaeontologica Polonica, 50, 743-755.

Barrenechea, J.F., Rodas, M. \& Mas, J.R. 1995. Clay mineral variations associated with diagenesis and low-grade metamorphism of early cretaceous sediments in the Cameros basin, Spain. Clay Minerals, 30, 119-133.
Barrenechea, J.F., Rodas, M., Frey, M., Alonso, A., Azcárate, J. \& Mas, J.R. 2001. Clay diagenesis and low-grade metamorphism of Tithonian and Berriasian sediments in the Cameros Basin (Spain). Clay Minerals, 36, 325-333.

Bataller, J.R. 1960. Los vertebrados del Cretácico inferior español. Notas y Comunicaciones del Instituto Geológico y Minero de España, 60, 141-164.

Bennett, C. 1997. Terrestrial locomotion of pterosaurs: a reconstruction based on Pteraichnus trackways. Journal of Vertebrate Paleontology, 17, 104-173.

Bernier, P., Barale, G., Bourseau, J.P., Buffetaut, E., Demathieu, G.R., Gaillard, C. \& Gall, J. 1982. Trace nouvelle de locomotion de chélonien et figures d'émersion associées dans les calcaires lithographiques de Cerin (Kimmeridgien supérieur, Ain, France). Geobios, 15, 447-467.

Bernier, P., Barale, G., Bourseau, J.P., Buffetaut, E., Demathieu, G.R., Gaillard, C., Gall, J.C. \& Wenz, S. 1984. Decouverte de pistes de dinosaures sauteurs dans les calcaires lithographiques de Cerin (Kimmeridgien superieur, Ain, France) implications paleoecologiques. Geobios, 8, 177-185.

Beuther, A. 1966. Geologische Untersuchungen in Wealden und Utrillas-Schichten in Westteil der Sierra de los Cameros (Nordwestliche Iberische Ketten). Beihefte zum Geologischen Jahrburch, 44, 103-121.

Billon-Bruyat, J.P. \& Mazin, J.M. 2003. The systematic problem of tetrapod ichnotaxa: the case study of Pteraichnus Stokes, 1957 (Pterosauria, Pterodactyloidea). Geological Society, London Special Publications, 217, 315-324.

Buffetaut, E. 1999. Pterosauria from the Upper Cretaceous of Laño (Iberian Peninsula): a preliminary comparative study. Estudios del Museo de Ciencias Naturales de Álava, 14, 289-294.

Buscalioni, A.D. \& Martínez-Salanova, J. 1990. Los Vertebrados fósiles del yacimiento Cretácico de Armuña (Prov. Segovia, España). Comunicaciones de la Reunión de Tafonomía y Fosilización, 51-57.

Carroll, R.L. 1988. Vertebrate Paleontology and evolution. W.H. Freeman and Company, New York, 698 pp.

Clark, J.M., Hopson, J.A., Hernández, R., Fastovsky, D.E. \& Montellano, M. 1998. Foot posture in a primitive pterosaur. Nature, 391, 886-889.

Company, J., Unwin, D.M., Pereda-Suberbiola, X. \& RuizOmeñaca, J.I. 2001. A giant Azhdarchid pterosaur from the Latest Cretaceous of Valencia, Spain - The largest flying creature ever? Journal of Vertebrate Paleontology, 21, 41A.

Cuenca-Bescós, G., Amo, O., Aurell, M., Buscalioni, A.D., Canudo, J.I., Laplana, C., Pérez, J., Ruiz-Omeñaca, J.I., Sanz, J.L. \& Soria, A.R. 1994. Los vertebrados del tránsito Jurásico-Cretácico de Galve (Teruel). X Jornadas de la Sociedad Española de Paleontología, 50-53.

De Broin, F. \& Murelaga, X. 1999. Turtles from the Upper Cretaceous of Laño (Iberian Peninsula). Estudios del Museo de Ciencias Naturales de Álava, 14, 135-211.

Delair, J.B. 1963. Notes on Purbeck fossil footprints, with description of two hitherto unknown forms from Dorset. Proceedings of the Dorset Natural History and Archaeological Society, 84, 92-100. 
Doublet, S., García, J.P., Guiraud, M. \& Ménard, A. 2003. Wave-dominated siliciclastic and carbonate sedimentation in a Lower Cretaceous lake (Cameros basin, northern Spain). Journal of Iberian Geology, 29, 11-28.

Fiorillo, A.R. 2005. Turtle tracks in the Judith River Formation (Upper Cretaceous) of South Central Montana. $\mathrm{Pa}$ leontologia Electronica, 8, 9A, 11pp.

Foster, J.R., Lockley, M.G. \& Brockett, J. 1999. Possible turtle tracks from the Morrison Formation of Southern Utah. Vertebrate Paleontology in Utah, 99, 185-191.

Fuentes, C. 2001. A new species of Pteraichnus from the Spanish Lower Cretaceous: Pteraichnus cidacoi. Strata, 11, 44-46.

Fuentes, C. \& Meijide Calvo, M. 1996. Restos de Pterosaurios en el "Weald" de Soria (España). Stvdia Geologica Salmanticensia, 32, 15-22.

Fuentes, C., Meijide Calvo, M. \& Meijide Fuentes, F. 2003a. Nueva tortuga para el Cretácico Inferior de Salas de los Infantes (Burgos, España): Salasemys pulcherrima nov. gen. nov. sp. Stvdia Geologica Salmanticensia, 39, 109-123.

Fuentes, C., Meijide Calvo, M., Meijide Fuentes, F. \& Meijide Fuentes, M. 2003b. Rastro de un pequeño tetrápodo de pequeño tamaño en el Weald de Cameros (Sierra de Oncala, Soria, España) nov. icnogen. nov. icnosp: Emydhipus cameroi. In: Dinosaurios y Otros Reptiles Mesozoicos en España. Ciencias de la Tierra, 26. Instituto de Estudios Riojanos, 119-128.

Fuentes, C., Meijide Calvo, M., Meijide Fuentes, F. \& Meijide Fuentes, M. 2008. Huellas de una gran tortuga terrestre en el Cretácico Inferior (Berriasiense) de la Sierra de Oncala (Soria, España). XXIV Jornadas de la Sociedad Española de Paleontología, Colunga (Asturias), 30.

Gaillard, C., Bernier, P., Barale, G., Boursseau, J.P., Buffetaut, E., Ezquerra, R., Gall, J.C., de Lapparent de Broin, F., Renous, S. \& Wenz, S. 2003. A giant Upper Jurassic turtle revealed by its trackways. Lethaia, 36, 315-322.

García-Ramos, J.C., Lires, J. \& Piñuela, L. 2002. Dinosaurios. Rutas por el Jurásico de Asturias. Grupo Zeta, Oviedo, $204 \mathrm{pp}$.

Guimerà, J., Alonso, A. \& Mas, J.R. 1995. Inversion of an extensional-ramp basin by a newly formed thrust: the Cameros basin (N. Spain). In: Basin Inversions (eds. J.G. Buchanan \& P.G. Buchanan). Geological Society, London, Special Publication, 88, 433-453.

Jiménez, E. 1987. Consideraciones taxonómicas sobre algunos Quelonios fósiles de España. II Congreso Nacional de Herpetología, 57.

Jiménez, E. 1995. Turtles. En: Las Hoyas, a lacustrine Konservat-Lagerstätte, Cuenca (ed. N. Meléndez). Field Trip Guide Book, II International Symposium on Lithographic Limestones, Cuenca, Spain, 55-56.

Jiménez, E., Martín, J., Mulas, E. \& Pérez, E. 1990. Yacimientos con quelonios del Cretácico español. Actas de las IV Jornadas de la Sociedad Española de Paleontología, 68, 173-176.

Krebs, B. 1995. The Barremian vertebrate locality Uña (province of Cuenca) materials for a comparison with Las
Hoyas. II International Symposium on Lithographic Limestones, Cuenca, Spain, 95-97.

Kubo, T. 2008. In quest of the Pteraichnus trackmaker: comparisons to modern crocodilians. Acta Palaeontologica Polonica, 53, 405-412.

Li, D., Azuma, Y., Fujita, M., Lee, Y.N. \& Arakawa, Y. 2006. A preliminary report on two new vertebrate track sites including dinosaurs from the Early Cretaceous Hekou Group, Gansu province, China. Journal of Paleontological Society of Korea, 22, 29-49.

Lockley, M.G. 1999. Pterosaur and bird tracks from a new Late Cretaceous locality in Utah. In: Vertebrate Paleontology in Utah (ed. D.D. Gillette). Utah Geological Survey, 355-359.

Lockley, M.G. \& Foster, J. 2006. Dinosaur and turtle tracks from the Morrison Formation (Upper Jurassic) of Colorado National Monument, with observations on the taxonomy of vertebrate swim tracks. Paleontology and Geology of the Upper Jurassic Morrison Formation. New Mexico Museum of Natural History and Science Bulletin, 36, 193-198.

Lockley, M.G., Logue, T.J., Moratalla, J.J., Hunt, A.P., Schultz, R.J. \& Robinson, A.P. 1995. The fossil trackway Pteraichnus is pterosaurian, not crocodilian: implications for the global distribution of pterosaur tracks. Ichnos, 4, 7-20.

Lockley, M.G., Foster, J. \& Hunt, A. 1998. A short summary of dinosaur tracks and other fossil footprints from the Morrison Formation. Modern Geology, 24, 179-203.

Lockley, M.G., Wright, J.L., Langston, W. \& West, E.S. 2001. New pterosaur track specimens and tracksites in the Late Jurassic of Oklahoma and Colorado: their paleobiological significance and regional ichnological context. Modern Geology, 24, 179-203.

Lockley, M.G., Kukihara, R. \& Mitchell, L. 2006. New dinosaur and crocodile tracksites from the Cretaceous Dakota Group of the Colorado Front Range, Boulder and Jefferson Counties, Colorado. New Mexico Museum of Natural History and Science Bulletin, 35, 89-94.

Malod, J.A. \& Mauffret, A. 1990. Iberian plate motions during the Mesozoic. Tectonophysics, 184, 261-278.

Mas, J.R., Alonso, A. \& Guimerà, J. 1993. Evolución tectosedimentaria de una cuenca extensional intraplaca: La cuenca finijurásica - eocretácica de Los Cameros (La Rioja - Soria). Revista de la Sociedad Geológica de España, 6, 129-144.

Mas, R., Benito, M.I., Arribas, J., Serrano, A., Guimerà, J., Alonso, A. \& Alonso-Azcárate, J. 2002. La Cuenca de Cameros: desde la extensión finijurásica-eocretácica a la inversión terciaria-implicaciones en la exploración de hidrocarburos. In: Aspectos naturalísticos de Los Cameros I. Geología (ed. F. Pérez-Lorente). Zubía Monográfico, 14, 9-64.

Mas, R., Benito, M.I., Arribas, J., Serrano, A., Guimerà, J., Alonso, A. \& Alonso-Azcárate, J. 2003. The Cameros Basin: from Late Jurassic-Early Cretaceous extension to Tertiary contractional inversion-implications of Hydrocarbon exploration. Geological Field Trip 11, AAPG International Conference and Exhibition, Barcelona, 2003, 1-56. 
Mazin, J.M., Hantzpergue, P., Lafaurie, G. \& Vignaud, P. 1995. Des pistes de ptérosaures dans le Tithonien de Crayssac (Quercy, France). Comptes Rendus de l'Académie des Sciences, 321, 417-424.

Mazin, J.M., Billon-Bruyat, J.R., Hantzpergue, R. \& Lafaurie, G. 2003. Ichnological evidence for quadrupedal locomotion in pterodactyloid pterosaurs: trackways from the Late Jurassic of Crayssac (southwestern France). Geological Society, London, Special Publications, 217, 283-296.

Meijide Calvo, M. 2001. Pterosaur trace in Oncala Berriasian (Soria, Spain). New ichnospecies: Pteraichnus manueli. Strata, 11, 72-74.

Meijide Fuentes, F. 2001. Pterosaur tracks in Oncala Mountain Range (Soria, Spain). A new ichnospecies: Pteraichnus vetustior. Strata, 11, 70-71.

Meijide Calvo, M. \& Fuentes, C. 1999. Huellas de Pterosaurios en el Weald de Soria (España). I Jornadas Internacionales de Paleontología de Dinosaurios y su entorno, Salas de los Infantes (Burgos, España), 397-406.

Mezga, A. \& Bajraktarevic, Z. 2004. Cretaceous dinosaur and turtle tracks on the island of Veli Brijun (Istria, Croatia). Geologica Carphatica, 55, 355-370.

Moratalla, J.J. 1990. Un icnita de quelonio en el Cretácico inferior de La Rioja (España). Actas de las IV Jornadas de la Sociedad Española de Paleontología, 68, 255-261.

Moratalla, J.J. 1993. Restos indirectos de dinosaurios del registro español: Paleoicnología de la Cuenca de Cameros (Jurásico superior-Cretácico inferior) y Paleoología del Cretácico superior. PhD Thesis. Universidad Autónoma de Madrid, 727 pp. (unpublished)

Moratalla, J.J. 2002. Cameros Basin Megasequence (Spain): an overview on body and ichnological biodiversity from the European Cretaceous. Journal of Vertebrate Paleontology, 22 (sup. $n^{\circ} 3$ ), 90A.

Moratalla, J.J. \& Sanz, J.L. 1997. Cameros Basin Megatracksite. In: Enciclopedia of Dinosaurs (eds. P.J. Currie \& K. Padian). Academic Press, San Diego, 87-90.

Moratalla, J.J., Sanz, J.L. \& Jiménez, S. 1997. Información paleobiológica y paleoambiental inferida a partir de las icnitas de dinosaurios: problemas, límites y perspectivas. Estrato, 12, 185-196.

Moratalla, J.J., Sanz, J.L. \& Jiménez, S. 2001. Yacimiento de icnitas de La Virgen del Prado (Inestrillas-Aguilar del Río Alhama) y excavaciones en Sol de la Pita 2 (Préjano) y La Llana (Aguilar del Río Alhama). Estrato, 11, 92-97.

Moratalla, J.J., Hernán, J. \& Jiménez, S. 2003. An Overview on the Lower Cretaceous Ichno-Diversity of the Cameros Basin (Cornago, La Rioja Province, Spain). Ichnos, 10, 229-240.

Murelaga, X. 1997. Primeros restos de tortugas del Cretácico inferior (Barremiense superior) de Vallipón (Castellote, Teruel). Mas de las Matas, 17, 189-200.

Owen, R. 1874. Monograph on the Fossil Reptilia of the Liassic Formations. Monographs of the Palaeontographical Society, London, 1-14.

Padian, K. 1983. A functional analysis of flying and walking in pterosaurs. Paleobiology, 9, 28-239.

Padian, K. 1984. The Origin of Pterosaurs. Third Symposium on Mesozoic Terrestrial Ecosystems Short Papers (eds. W.E. Reif \& F. Westphal). Attempto, Tübingen, 163-168.

Padian, K. 1985. The origins of aerodynamics of flight in extinct vertebrates. Palaeontology, 28, 413-433.

Padian, K. 1987. The case of the bat-winged pterosaur. Typological taxonomy and the influence of pictorial representation on scientific perception. In: Dinosaurs Past and Present 2 (eds. S.J. Czerkas \& E.C. Olson). Natural Museum of Los Angeles County and University of Washington Press, 65-81.

Padian, K. 1988. The flight of pterosaurs. Natural History, 97, 58-65.

Padian, K. 1991. Pterosaurs: were they functional birds or functional bats? In: Biomechanics in evolution (eds. J.M.V. Rayner \& R.J. Wooton). Seminar Series of the Society for Experimental Biology 36, Cambridge University Press, 146-160.

Padian, K. \& Olsen, P,E. 1984. The fossil trackway Pteraichnus: not pterosaurian, but crocodilian. Journal of $\mathrm{Pa}$ leontology, 58, 178-184.

Padian, K. \& Rayner, J.M.V. 1993. The wings of pterosaurs. American Journal of Science, 293A, 91-166.

Palacios, P. \& Sánchez, R. 1885. La Formación Wealdense en las provincias de Soria y Logroño. Boletín de la Comisión del Mapa Geológico de España, 12, 109-140.

Pascual, C. \& Sanz, E. 2000. Huellas de pterosaurios en el grupo Oncala (Soria, España). Pterichnus palaciei-saenzi, nov. icnosp. Estudios Geológicos, 56, 73-100.

Paul, G.S. 1987. Pterodactyl habits - real and ratio controlled. Nature, 328, 481.

Pennycuick, C.J. 1986. Mechanical constraints on the evolution of flight. In: The origin of Birds and the Evolution of Flight (ed. K. Padian). Memoirs of the California Academy of Sciences, 8, 83-98.

Pereda-Suberbiola, X. \& Astibia, H. 1993. El yacimiento paleontológico de Laño. Política Científica, 36, 48-51.

Pereda-Suberbiola, X., Corral, C., García-Garmilla, F. \& Astibia, H. 1992. Tafonomía del yacimiento de vertebrados de Laño (Cretácico superior, Cuenca Vasco-Cantábrica): Datos preliminares. VIII Jornadas de la Sociedad Española de Paleontología, 119-120.

Pérez-Arlucea, M. \& Smith, N.D. 1999. Depositional patterns following the 1870s avulsion of the Saskatchewan River (Cumberland Marshes, Saskatchewan, Canada). Journal of Sedimentary Research, B69, 62-73.

Pérez-Lorente, F. 1987. La estructura del borde Norte de la Sierra de Cameros (La Rioja). Boletín del Instituto Geológico y Minero de España, 98, 484-492.

Pérez-Lorente, F., Romero, M.M., Requeta, E., Blanco, M.I. \& Caro, S. 2001. Dinosaurios. Introducción y análisis de algunos yacimientos de sus huellas en La Rioja. Instituto de Estudios Riojanos (Ciencias de la Tierra, 24), $102 \mathrm{pp}$.

Peybernès, B. 1982. Creation puis evolution de la marge Nord-Iberique des Pyrenees au Crétacé inférieur. Cuadernos de Geología Ibérica, 8, 987-1004.

Pinheiro, L.M., Wilson, R.C.L., Pena-dos-Reis, R., Whitmarsh, R.B.\& Ribeiro, A. 1996. The western Iberia mar- 
gin: a geophysical and geological overview. Proceeding of the Ocean Drilling Program, Scientific Results (eds. R.B. Whitmarsh, D.S. Sawyer, A. Klaus \& D.G. Masson), 149, 3-23.

Platt, N.H. \& Wright, V.P., 1991. Lacustrine carbonates: facies models, facies distributions and hydrocarbon aspects" en Lacustrine Facies Analysis. Special Publication of the International Association of Sedimentologists (eds. P. Anadón, L. Cabrera \& Kelts), 3, 57-74.

Royo y Gómez, J. 1918. Los yacimientos weáldicos del Maestrazgo. Boletín de la Real Sociedad Española de Historia Natural, 20, 261-267.

Royo y Gómez, J. 1921. La facies continental en el Cretácico inferior ibérico. Asociación Española para el Progreso de las Ciencias. Oporto-Sección $4^{a}$ Ciencias Naturales, 321-336.

Salas, R., Guimerà, J., Mas, R., Martín-Closas, C., Meléndez, A. \& Alonso, A. 2001. Evolution of the Mesozoic Central Iberian Rift System and its Cainozoic inversion (Iberian Chain). In: Peri-Tethyan rift/wrench basins and passive margins (eds. P.A. Ziegler, W. Cavazza, A.H.F. Robertson \& S. Crasquin-Soleau). Mémoires du Muséum National d'Histoire Naturelle, 186, 145-186.

Sanz, J.L., Moratalla, J.J., Rubio, J.L., Fuentes, C. \& Meijide Calvo, M. 1997. Huellas de dinosaurios de Castilla y León. Junta de Castilla y León. Consejería de Educación y Cultura, Diputación Provincial de Burgos, Diputación Provincial de Soria, 87 pp.

Seeley, H.G. 1875. On the Ornithosaurian (Doratorhynchus validus) from the Purbeck Limestone of Langton near Swanage. Quarterly Journal of the Geological Society, London, 31, 465-468.

Seeley, H.G. 1887. On a Sacrum, apparently indicating a new type of Bird, Ornithodesmus cluniculus, Seeley, from the Wealden of Brook. Quarterly Journal of the Geological Society, London, 43, 206-211.

Smith, N.D. \& Pérez-Arlucea, M. 1994. Fine-grained splay deposition in the avulsion belt of the Lower Saskatchewan River, Canada. Journal of Sedimentary Research, B64, 159-168.

Smith, N.D., Cross, T.A., Dufficy, J.P. \& Clough, S.R. 1989. Anatomy of an avulsion. Sedimentology, 36, 1-23.

Stokes, W.L. 1957. Pterodactyl tracks from the Morrison Formation. Journal of Paleontology, 31, 952-954.

Thulborn, R.A. 1989. The gaits of dinosaurs. In: Dinosaur Tracks and Traces (eds. D.D. Gillette \& M.G. Lockley). Cambridge University Press, 39-50.

Tischer, G. 1966a. Uber die Wealden-Ablagerung und die Tektonik der östlichen Sierra de los Cameros in den nordwestlichen Iberischen Ketten (Spanien). Beihefte zum Geologischen Jahrburch, 44, 123-164.

Tischer, G. 1966b. El delta wealdico de las montañas Ibéricas occidentales y sus enlaces tectónicos. Notas y Comu- nicaciones del Instituto Geológico y Minero de España, 81, 53-78.

Torcida, F. 1996. Registro de dinosaurios en el sureste de la Provincia de Burgos. Zubía, 14, 89-104.

Torcida, F. 2006. Restos directos de dinosaurios en Burgos (Sistéma Ibérico): un balance provisional. Actas de las III Jornadas sobre Dinosaurios y su Entorno, Colectivo Arqueológico-Salense, 105-128.

Tye, R.S. \& Coleman, J.M. 1989a. Evolution of Atchafalaya lacustrine deltas, south-central Louisiana. Sedimentary Geology, 65, 95-112.

Tye, R.S. \& Coleman, J.M. 1989b. Depositional processes and stratigraphy of fluvially dominated lacustrine deltas: Mississippi delta plain. Journal of Sedimentary Petrology, 59, 973-996.

Unwin, D.M. 1987. Pterosaur locomotion. Joggers or waddlers? Nature, 327, 13-14.

Unwin, D.M. 1989. A Predictive Method of the Identification of Vertebrate Ichnites and its Application to Pterosaur Tracks. In: Dinosaur Tracks and Traces (eds. D.D. Gillette \& M.G. Lockley). Cambridge University Press, 259-274.

Unwin, D.M. 1997. Pterosaur tracks and the terrestrial ability of pterosaurs. Lethaia, 29, 373-386.

Vera, J.A. 2001. Evolution of the South Iberian Continental Margin. In: Peri-Tethyan rift/wrench basins and passive margins (eds. P.A. Ziegler, W. Cavazza, A.H.F. Robertson \& S. Crasquin-Soleau). Mémoires du Muséum National d'Histoire Naturelle, 186, 109-143.

Vergés, J. \& García-Senz, J. 2001. Mesozoic evolution and Cainozoic inversion of the Pyrenean Rift. In: Peri-Tethyan rift/wrench basins and passive margins (eds. P.A Ziegler, W. Cavazza, A.H.F. Robertson \& S. CrasquinSoleau). Mémoires du Muséum National d'Histoire Naturelle, 186, 187-212.

Wellnhofer, P. 1988. Terrestrial locomotion in pterosaurs. Historical Biology, 1, 3-16.

Wellnhofer, P. 1991. The Illustrated Encyclopedia of Pterosaurs. Salamander Books, London, 192 pp.

Wellnhofer, P. \& Vahldiek, B.W. 1986. Ein Flugsaurier-Rest aus dem Posidonienshiefer (Unter-Toarcian) von Schandelah bei Braunschweig. Paläontologische Zeitschrift, 60, 329-340.

Wright, J. \& Lockley, M.G. 2001. Dinosaur and turtle tracks from the Laramie/Arapahoe formations (Upper Cretaceous), near Denver, Colorado, USA. Cretaceous Research, 22, 365-376.

Wright, J.L., Unwin, D.M., Lockley, M.G. \& Rainforth, E.C. 1997. Pterosaur tracks from the Purbeck Limestone Formation of Dorset, England. Proceedings of the Geologists' Association, 108, 39-48.

Manuscrito recibido: 28 de Octubre, 2008 Manuscrito aceptado: 30 de Abril, 2009 
